\title{
Mixed Methods Utilisation in Innovation Management Research: A Systematic Literature Review and Meta-Summary
}

\author{
Klaudia Bracio ${ }^{1, *(D)}$ and Marek Szarucki ${ }^{2}$ (D) \\ 1 Doctoral School, Cracow University of Economics, 27 Rakowicka St., 31-510 Krakow, Poland \\ 2 Department of Strategic Analysis, College of Management Sciences and Quality, Cracow University \\ of Economics, 27 Rakowicka St., 31-510 Krakow, Poland; szaruckm@uek.krakow.pl \\ * Correspondence: klaudiabracio@gmail.com
}

Received: 31 August 2020; Accepted: 16 October 2020; Published: 27 October 2020

\begin{abstract}
The main purpose of this article is to explore the application of mixed methods research in the innovation management sub-discipline utilizing a systematic literature review and meta-summary analysis. Regardless of the growing number of studies in innovation management there is still a lack of research that integrates and synthesizes this body of knowledge. Our review of 93 articles from Web of Science and Scopus databases, including content analysis, presents trends and research background in innovation management that use the mixed methods approach. This study addresses the inconsistencies in the literature and presents a holistic picture of what existing empirical studies have found to date. In addition, we have developed an innovation management model based on selected theoretical lenses to enable future researchers in a given area to choose the appropriate method. The results of the meta-summary show that $50.54 \%$ articles from our dataset are related to partially mixed dominant sequential methods, $12.90 \%$ fully mixed dominant sequential methods and $11.83 \%$ fully mixed dominant concurrent methods. We identified several research gaps and provided a future research avenue in the context of innovation management. The article analyzes empirical papers, enables identification of problems in the current research and identifies trends in the area of the studied phenomenon. The results on the topic of mixed methods in innovation management and used tools have indicated that this issue is still in a premature phase but with an upward trend of research development.
\end{abstract}

Keywords: mixed methods research; mixed research approaches; mixed research models; innovations; innovation management

\section{Introduction}

One of the most important and sustainable sources of long-term success of organizations is innovation (Camisón and Villar-López 2014; Iturrioz et al. 2015). Over the last 45 years the body of innovation management literature grew considerably especially in the area of innovation, innovation management or commercialization of innovation. This led to an increasing number of different models of innovation processes, especially in the field of innovation management research, from research on the impact of creative thinking on green innovations (Awan et al. 2019) and the innovative behavior of high-tech businesses (Wach 2016) to the use of managerial competencies and innovation in enterprises (Szczepańska-Woszczyna and Dacko-Pikiewicz 2014; Okoń-Horodyńska et al. 2020; Szczepańska-Woszczyna 2020).

Mixed research methods are one of the most important and the most effective ways of generating more accurate results in order to provide a broader and more complete vision of a problem in management research (Bazeley 2015). 
The area of innovation management (Ritala et al. 2020) is studied both with the help of two groups of research methods: quantitative methods (e.g., to study expenditures on innovations or dynamics of start-up development) (Awan 2020; Faems 2020), as well as qualitative methods (Goffin et al. 2019), as innovations are complex and multidimensional processes. Many researchers indicate that only by employing mixed methods the most accurate measurements of innovation management can be achieved. Therefore, it is supposed that there is a relationship between the use of mixed research methods in the articles and obtaining results that are more accurate. Many innovation management tools are used in this discipline, the use of which has real effects. With the development of research and the deepening of knowledge on innovation management, many researchers are verifying the usefulness of existing innovation management tools and developing new ones. Nevertheless, to the best of our knowledge, there are no studies extensively exploring the application of mixed methods within the area of innovation management research, since most of them concentrate on general management (Cameron and Molina-Azorin 2011; Bazeley 2015; Molina-Azorin et al. 2017). For this reason, presenting a review of literature and meta-summary in a given field seems to be scientifically justified.

Considering these gaps in the literature, and the scholars' calls to address the absence of systematic reviews regarding innovation management (Cameron and Molina-Azorin 2011; Lopes et al. 2016), specifically in the area of application of mixed method approaches, our main goal is to explore the application of mixed methods research in the innovation management sub-discipline using a systematic literature review and meta-summary analysis. More specifically, the present study first undertakes a systematic review of the literature in order to identify drivers and outcomes of using mixed methods in the articles on innovation management. We explore the relationships between the use of mixed research methods in the innovation management sub-discipline with all drivers and outcome variables that have been empirically studied in the systematic review. Second, we conduct a meta-summary to further explore drivers and outcomes of using mixed methods in innovation management research, where adequate independent empirical studies are available.

This article contributes to the literature on innovation management research in various ways. First, it synthesizes the contributions of research published in the innovation management sub-discipline. Second, it develops a framework that covers studies on mixed methods in innovation management research. Third, it uses a meta-summary method to aggregate prior empirical studies on innovation management to identify the direction and effect of mixed methods used in the field of innovation management discipline. Fourth, through the critical analysis of the literature, this study highlights the gaps in the literature and provides suggestions for future studies to further explore the field. This is critical given that the field of innovation management sub-discipline is still in its infancy stage and, therefore, research on using mixed methods in innovation management research is strong in certain areas but weak in others.

\section{Mixed Methods and Innovation Management Research}

\subsection{Definition of Mixed Methods Approach}

Looking from the historical perspective, the mixed methods approach can be perceived as a methodology developed around the end of 1980s and beginning of 1990s, which, in its present form, stemmed from the work of researchers in various scientific fields, such as sociology, education, management, and health sciences (Creswell and Creswell 2018). Mixed methods research (the combined use of quantitative and qualitative methods in the same study) is becoming an increasingly popular approach in the discipline fields of many sciences. The main feature of mixed methods research is its methodological pluralism, which frequently results in research, which provides broader perspectives than those offered by monomethod designs.

Calls for the integration of quantitative and qualitative research methods have been announced in social sciences (Denscombe 2008) especially in the business and management discipline areas 
(Cameron and Molina-Azorin 2011). On the other hand, management researchers trying to utilize a mixed methods approach may still encounter opposition from the guards of a discipline where research is heavily inculcated with a positivist ideology, an adoration of indicators, measures, and an assumption of developing statistical analyses of numeral data (Currall and Towler 2003).

The growing use of mixed methods has practical implications for research training and capacity building within business schools (Cameron 2011; Frias and Popovich 2020). Therefore, there is an increasing need to develop research capacity through the introduction of postgraduate courses in mixed methods and advanced research skills training for existing researchers.

W.E. Thurston, L. Cove, L.M. Meadows (Thurston et al. 2008) indicated that a single definition of mixed methods research does not exist, as "mixed methods studies can either combine methods from different paradigms or use multiple methods within the same paradigm, or multiple strategies within methods". One of the most popular definitions found in The Journal of Mixed Methods Research (Tashakkori and Creswell 2007), in its call for papers, defines mixed methods as "research in which the investigator collects, analyses, mixes, and draws inferences from both quantitative and qualitative data in a single study or a program of inquiry". In this paper, the following definition supplied by Greene et al. (1989) is applied, where mixed methods research designs are perceived as those that include at least one quantitative method (designed to collect numbers) and one qualitative method (designed to collect words).

A monomethod study uses only one type of method, one qualitative or one quantitative. In general, in a qualitative study, the information, which is mainly in textual form, is analyzed employing qualitative data analysis techniques. In a quantitative study, the data is in numerical form and this information is analyzed using quantitative data analysis techniques. Drawing an initial distinction between monomethod research and multiple methods research may be helpful to determine what is understood as "mixed methods". A multiple methods study uses more than one method. Moreover, a differentiation can be made within multiple method designs between multimethod research (multiple qualitative or quantitative methods) and mixed methods research (integration of quantitative and qualitative methods) (Creswell and Clark 2017).

The need to combine methods is due to the complexity of the object research, the need to enrich the results with different research perspectives and obtain a more complete and comprehensive picture of the reality being examined.

\subsection{The Application of Mixed Methods Research}

For researchers, two factors are most important: priority and implementation of data collection to design and conduct a mixed methods study (Morse 1991; Tashakkori and Teddlie 1998; Creswell and Clark 2017). Priority means that, depending on the researcher's preferences, research questions, and limitations in the possibilities of data collection, researchers can give equal priority to both quantitative and qualitative research or place more emphasis on qualitative or quantitative parts. Mixed methods designs can therefore be divided into the following categories: equivalent status designs and dominant-less dominant studies, or nested designs. Using the first model the researcher conducts the study using both the quantitative and qualitative approaches equally to understand the phenomenon under study. Using the other model, the researcher conducts the study within a single dominant paradigm with a small component of the overall study drawn from an alternative design.

Implementation of data collection refers to the sequence that the researcher uses to collect all data. If the research problem is solved by applying both qualitative methods as well as quantitative ones, the researcher uses a simultaneous, also referred to as concurrent, or parallel design. The relationship between methods can be equivalent (equal status of qualitative and quantitative paradigm) or leading for one of the methods (e.g., dominance of qualitative or quantitative method). In a sequential design, results obtained using one approach are the basis for research using the second approach. The third type of approach is transformational design. The transformational approach is characteristic of mixed methods used in evaluation studies being the basis for conducting economic research. In these studies, 
the test results are the basis for shaping social change that comes from the adopted theory. When the researcher has quantitative data, the goal is to test the variables on a large sample. To confirm the results obtained from a large sample, it is worth conducting a more in-depth analysis of several cases using qualitative methods. However, if qualitative data were collected, the intention is to first investigate the problem under study using qualitative methods, and then to continue this study using quantitative data that can be tested on a large sample so that the results can be deduced from the population.

Morse (Morse 1991) and Johnson and Onwuegbuzie (Johnson and Onwuegbuzie 2004) proposed four groups and nine types of mixed method projects with a combination of two dimensions. The dominant method is marked with capital letters (QUAN, QUAL), while the complementary method is represented by lowercase letters (quan, qual). The notation " + " means simultaneous design, and the arrow " $\rightarrow$ " is used to indicate a sequential design.

Equivalent status/simultaneous design: QUAL + QUAN.

Equivalent status/sequential designs: QUAL $\rightarrow$ QUAN; QUAN $\rightarrow$ QUAL.

Dominant/simultaneous designs: QUAL + quan; QUAN + qual.

Dominant/sequential designs: qual $\rightarrow$ QUAN; QUAL $\rightarrow$ quan; quan $\rightarrow$ QUAL; QUAN $\rightarrow$ qual.

\subsection{The Advantages and Limitations of Mixed Methods}

In the field of management research, a significant reflection prior to designing and conducting a mixed methods study is whether mixed methods, as compared to monomethod designs, best address the research questions and the research problems. Malan et al. (2019) described in detail that conducting a mixed methods study requires more work, time and financial resources. Additionally, increased demands on time depend on how long it takes to implement both aspects of the study.

In the field of management research, Jick (1979), Tashakkori and Teddlie (1998) and Creswell and Clark (2017) have been strong advocates for pluralism or multimethodology. Jick (1979) discussed triangulation in terms of the weaknesses of one method being offset by the strengths of another. It is often stressed that different methods have different weaknesses and strengths, and therefore the main effect that triangulation can offer is to overcome the weaknesses of any single method. Tashakkori and Teddlie have advised that better understanding and increasing the validity of inference can be obtained, for example, by triangulating one set of results with another. Additionally, "the use of quantitative and qualitative approaches in combination provides a better understanding of research problems than either approach alone" (Creswell and Clark 2017). Other advantages of using mixed methods in research include complementarity understood as complementing one method by another, initiation (the ability to exclude paradoxes and changing inappropriate research questions), extension by extending the scope of questions and answers and development (by using both methods in a given research area) Greene et al. (1989).

Other advantages presented by Bryman (2007) are: triangulation and analysis of processes and statistical features. Qualitative research can facilitate the interpretation of relationships between variables, because qualitative research facilitates quantitative research and quantitative research facilitates qualitative research.

Similar to the arguments above, Creswell and Creswell (2018, p. 281) have argued in favor of the advantages of using this type of approach by means of comparing various viewpoints obtained from quantitative and qualitative data, clarifying quantitative results with a qualitative complementary data collection and analysis, designing better contextualized measurement tools, augmenting experiments by including the perspectives of individuals, creating cases (i.e., organizations, units, or programs) for comparisons and obtaining a more complete perception of changes required for a marginalized group.

Despite the mentioned advantages of this sophisticated approach of conducting research, it is important to mention some challenges that may occur before starting a new research project 
(Creswell and Creswell 2018, p. 281): the need for large-scale data gathering, the time-consuming character of analyzing both qualitative and quantitative data and the necessity for the researcher to be acquainted with both quantitative and qualitative types of research. Moreover, due to the complexity of the research design it is important to develop clear, visual models to comprehend the specifics and the course of research activities within this approach. Bryman (2007) and Bryman (2007) mapped a brief division of barriers to using mixed methods research, pointing out that researchers need to develop a wider set of skills that span both the quantitative and qualitative research approaches. Another barrier is connected to the challenges of publishing mixed methods studies, such as word and page limits in journals (Wipulanusat et al. 2020).

\subsection{Innovation Management Research}

Innovation management is essentially perceived as inter-disciplinary research, where various theoretical and methodological concepts developed in business and management are applied, resulting in a separate sub-discipline of management (Tidd and Bessant 2018b). Within the literature, innovation management is referred to in many ways, routed in different theories that include new product development (Cooper 1990; Wheelwright and Clark 1992), technological innovation (Dosi 1982; Shea 2005; Nambisan and Nambisan 2008), process innovation (Tidd and Bessant 2018a), and open innovation (Sawhney and Prandelli 2000; Chesbrough et al. 2006).

The lack of a common definition of innovation is partly explained by referring to its multidisciplinary origin that influences the theory of innovation management. Two trends in innovation management influenced the basic idea of this paper. (Pereira and Leitão 2016)

Selection of the correct research method is one of the main fundamentals for success in the field of solving innovation problems. We were encouraged by the ideas of publications having methodological character that pay attention to methods, their development and applications, since comprehension and utilization of several different methods may cause some difficulties to researchers (Blumberg et al. 2011; Gupta and Trusko 2014). Moreover, notion innovation is very often connected with the questions of creativity, invention and intuition as expressions associated with newness. This fact was acknowledged, and the final method selection includes those methods that focus on gathering real data, data processing, analysis, etc. (so-called empirical or experiential methods) and the distinction between qualitative and quantitative methods. Study of innovation processes showed that it is necessary to apply a set of methods according to the way the innovative solution progresses. These so-called theoretical methods should be included in solving problems in the area of innovations, as those are usually verified by the internal logic reflection and relationship to business and commercial practice. There is a lack of comprehensive studies on utilizing the mixed methods approach in the innovation management subdiscipline. This research problem will be solved by applying an appropriate research methodology provided in the next section of the paper.

\section{Research Methodology}

A systematic literature review is the method that explores and sorts publications in order to identify the essential attributes of the studied materials. Moreover, the systematic literature review makes a special contribution in distinguishing past trends and forecasting future models, using a set of concepts, interpretative reflections, and analyzing all the evidence on a specific question (Rousseau et al. 2008). The advantage of this method is that it focuses on individual journal researches and chooses small samples or characteristics of cases according to the subject requirements and the interests of researchers (Aliaga-Isla and Rialp 2013).

According to the method applied, steps suggested by Tranfield et al. (2003), Aliaga-Isla and Rialp (2013) and Kitchenham (2004) are followed. In the planning stage, we prepared a study plan for review and developed a review protocol based on the objectives of the study. In the execution stage, we developed search keywords, identified the data sources, defined study selection criteria and 
extracted and synthesized data from selected studies. In the reporting stage, we reported our findings and explained the relationships between mixed methods and innovation management research.

Before the actual search for the articles, several initial searches of Scopus, Google Scholar and Web of Science were undertaken in order to determine keywords and appropriate search terms. All relevant keywords were searched in November 2019 as the next step. Electronic databases searched were Scopus and Web of Science.

For the literature search in the Web of Science and Scopus databases, we have applied a set of alternative keywords including such combinations as: "innovation management AND mixed methods", "mixed models AND innovation management", "quantitative and qualitative methods AND innovation management", "quantitative and qualitative research AND innovation management". Additionally, we made a manual search to find studies not included in the search of the databases.

We have only included the journals written in the English language. Nevertheless, all results should be treated with some reservation due to delays in publishing. In order to recognize the interest in the subject of mixed methods in innovation management research, we decided to search for articles from the Web of Science and Scopus databases. This is a typical procedure in this type of research order so as to increase reliability of results.

Based on the search criteria, we identified 1414 initial papers. It is common to retrieve a very large number of hits from the searches in databases. Therefore, once all studies had been retrieved from the databases, the inclusion and exclusion criteria were used to identify relevant studies. Initially, after applying two criteria: type-"article" and language-_English", 104 articles were found. The following documents were excluded: (1) in languages other than English, (2) book chapters, conference proceedings.

Firstly, we removed the duplicate publications (11) and this process brought down the number of studies to 93 . The first author then read the full text of the 93 articles and data from the 93 studies were extracted and synthesized for the purpose of systematic review (see Appendix A).

In the next stage, data from the 93 studies were extracted and synthesized for the purpose of systematic review. Data synthesis was achieved using content analysis. Content analysis is an established method of research and is used to condense a text into fewer content-related categories (Cavanagh 1997). Following Ritchie et al. (2013) method, a series of steps were undertaken in order to analyze the papers in our final pool. First, the literature was read and textually studied to derive a set of suitable categories. This led to identifying recurring themes and methods used in the papers from the collected literature. The extracted data was organized and examined based on method used in two main groups: non-empirical and empirical articles. Additionally, the group of empirical studies were divided into three types: quantitative, qualitative and mixed methods approach articles.

To lead the meta-summary, we used the Sandelowski and Barroso (2003) analytic guideline in this study. The approach includes the extraction, grouping, and formatting of findings, and the calculation of frequency and intensity effect sizes, which can be used to produce mixed research syntheses and to conduct analyses of the relationship between reports and findings. Additionally, meta-summaries can serve as a basis for a further synthesis.

The following studies were excluded from our meta-analysis: all articles in languages other than English and book chapters, conceptual studies, conference papers, and review papers, as we are interested in empirical evidence of mixed methods in innovation management research. We excluded studies that used the same dataset and stated the same correlations as in previously published papers.

The meta-summary examined relationships between the application and the characteristics of mixed methods in innovation management research. In the included studies, a sequential mixed methods study with two stages was undertaken to identify mixed methods articles and determine their main characteristics. In the first phase, a qualitative stage was used in the manual search strategy for the purpose of determining whether each article represented a non-empirical, quantitative, qualitative or mixed methods study. This deep analysis involved using all information presented in each article starting from the title, which is followed by keywords, abstract, introduction, literature review, methods, 
results, and finally discussion and conclusions. After a precise investigation of their content, including analysis of individual tables by journal and by year, listing the journal title, year, number of total articles, number of non-empirical articles, number of quantitative articles, number of qualitative articles and number of mixed methods articles. A database was created to compare different types of papers, techniques, methods, objects of analysis and a summary of findings. Once the mixed methods articles were identified, they were re-examined through a content analysis and coded according to two main dimensions: implementation of data collection (simultaneous or sequential) and priority (equal or dominant status of the quantitative and qualitative parts). In another phase, descriptive statistics were used for the quantitative analysis of prevalence, for providing sums and percentages depending on the type of article (non-empirical, quantitative, qualitative and mixed methods articles). Furthermore, regarding the mixed methods articles, numbers and percentages by type of priority (equal or dominant status), type of implementation (simultaneous or sequential) and purpose were also provided.

\section{Characteristics of the Included Studies}

As Figure 1 shows, the number of studies investigating the use of mixed methods approach in innovation management research has increased rapidly in recent years. There is a notable growth in publications from 2014, which suggests that mixed methods in innovation management research have grabbed the attention of academics as well as practitioners. Another purpose of the large number of publications in 2014 was raising the number of citations in the same year (see Figure 2). The observed number of citations shows small randomness in relation to the number of publications (see Figures 1 and 2), even considering the publishing cycle.

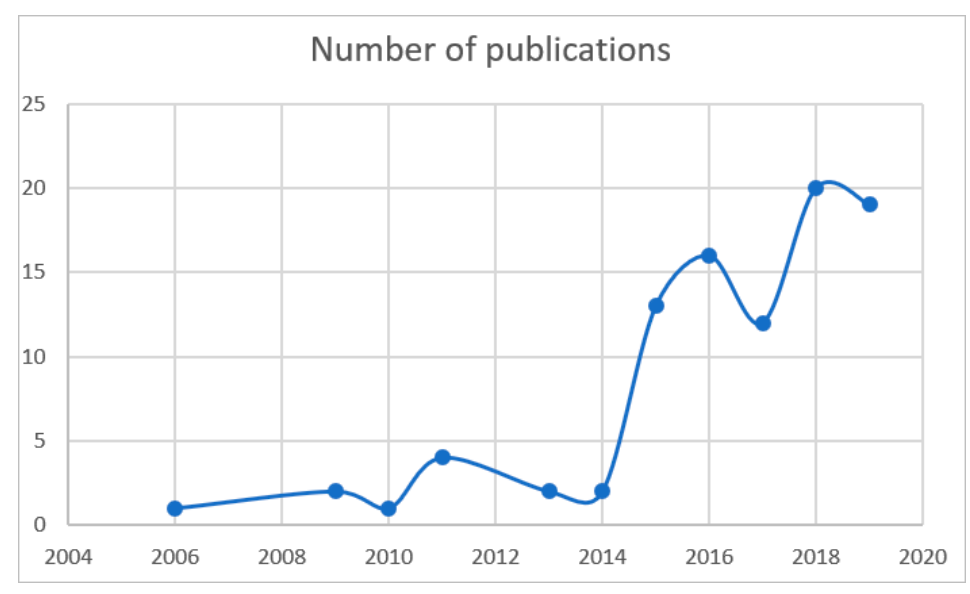

Figure 1. Number of publications of the studied literature collection (source: own study).

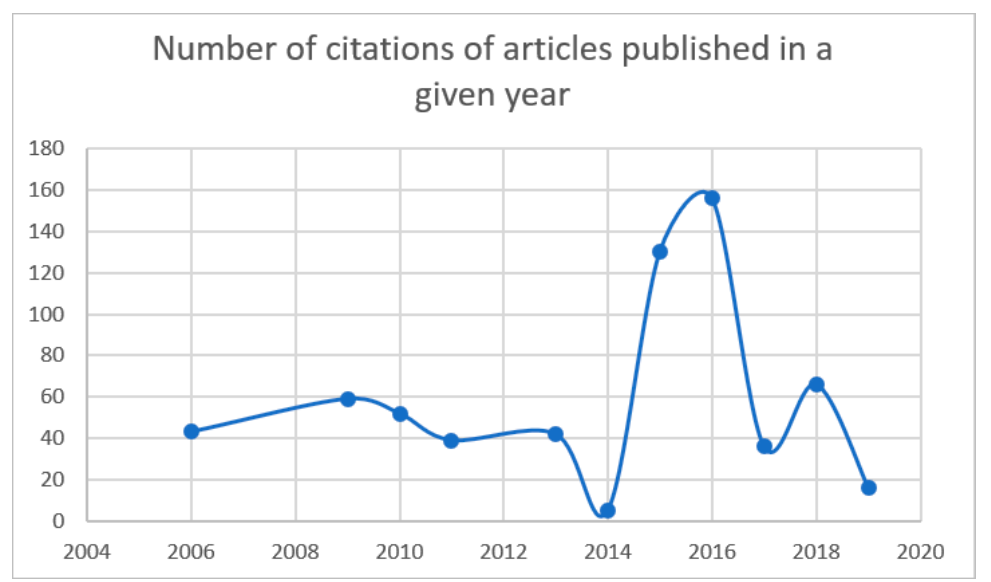

Figure 2. Number of citations of the studied literature collection (source: own study). 
This is due to two phenomena: the first is the high homogeneity of the publications, expressed by many citations (International Journal of Production Research and Journal of Product Innovation Management are the most appropriate journals for targeting texts related to this issue as those have the largest number of citations).

Only "Technological Forecasting and Social Change" has published five articles; they appear in stable time intervals $(2006,2015,2018,2019)$. The next are "R \& D Management", "Journal of Business Research", with four and three publications, respectively. "Technological Forecasting and Social Change" has (according to the average: 2006, 2015, 2018, 2019) the most recent articles of them all and is in an upward trend.

The second reason is the large number of publications in general, which is noticeable in the form of small fluctuations in the number of publications. During bibliometric analysis of 4185 references we noticed that 13 authors out of 314 worked on five publications from the collection. This indicates the lack of chances of specialization in the topic.

Compared with Lotka's schedule (Lotka 1926) in de Solla Price's interpretation (Price 1986), this is the number of publications above the elite borderline (i.e., 10 publications), since there is a theoretical capacity for the author who would be responsible for 13 publications (with $\mathrm{c}=314 n=2$ for Lotka's distribution should be 1.858 author with 13 publications). It is also an argument demonstrating that this topic started to be a part of knowledge on innovation management research.

We also examined the superficial content of the articles using the RAKE method (Berry and Kogan 2010) to identify keywords. The udpipe package (Straka and Straková 2017) for the language R (R Core Team 2018) was used for this purpose; the method was carried out on lemmas (basic forms of expression), so as not to multiply variations of the same phrases. The set of keywords identified from the abstracts is quite extensive (see Figure 3). The mixed methods approach shows the greatest link here as well as open innovation processes and innovation management and regional competitiveness. These are all concepts identified as essential for mixed methods in the innovation management topic, whose relationship with the examined subject is sometimes not obvious.

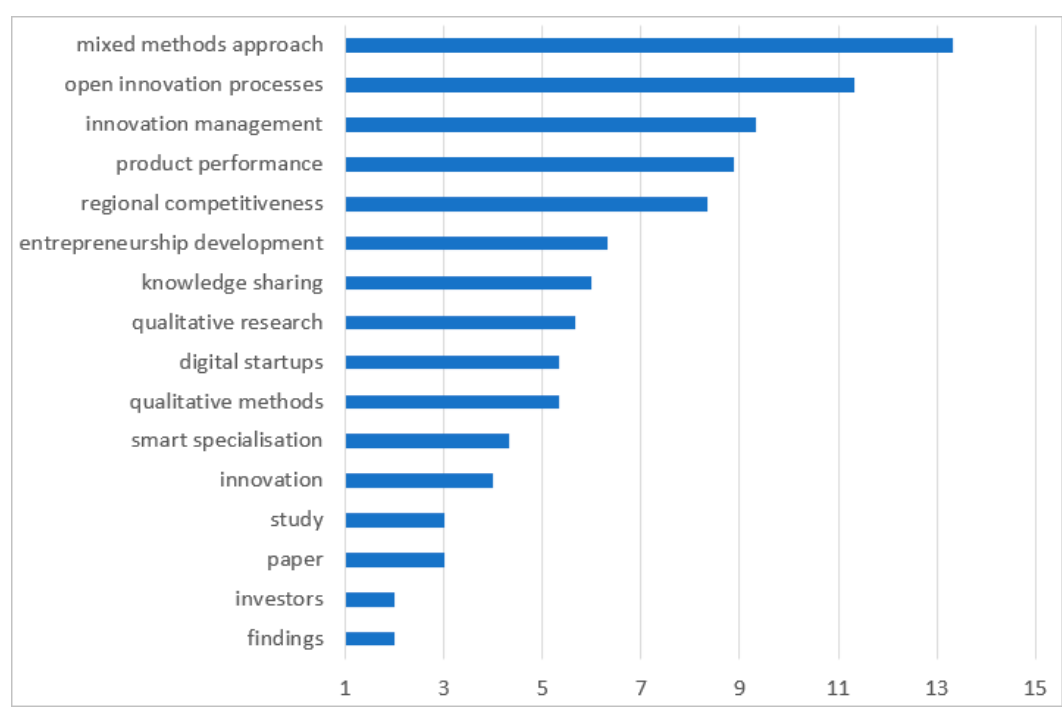

Figure 3. Identification of keywords by the Rapid Automatic Keyword Extraction method (RAKE) (source: own study).

We examine the recent information visualization phenomenon known as tag clouds, which are an interesting combination of data visualizations (Hearst and Rosner 2008). We used this method to compare the results using two different techniques. Figure 4 demonstrates that most keywords are repeated in both figures, which means two tests were carried out correctly. 


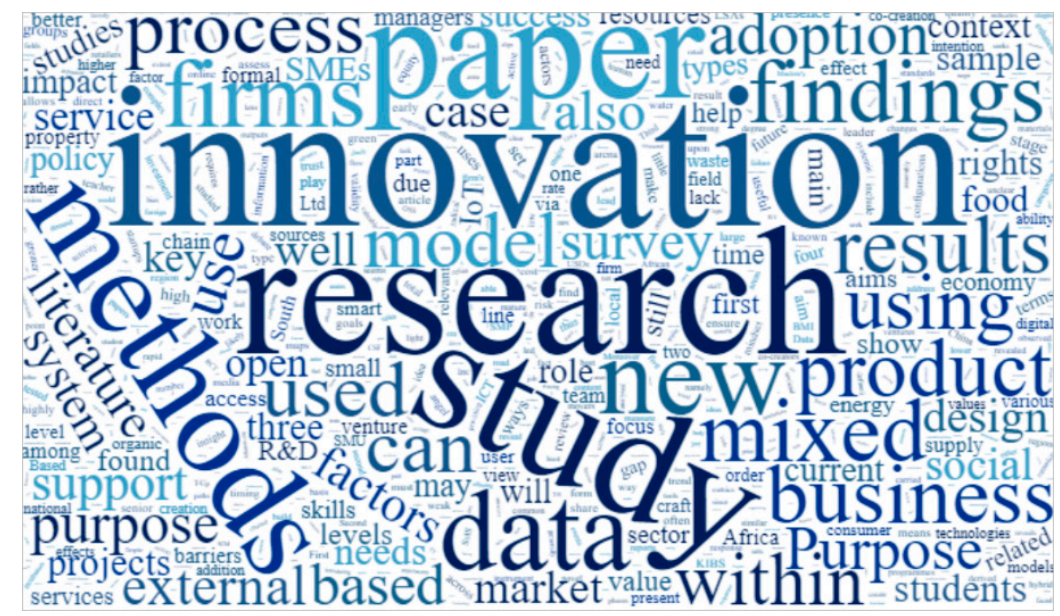

Figure 4. Identification of keywords in a tag cloud representation (source: own study).

After a summary review of the collection due to its separation, it is worth going back to the properties of the publications related to their individual characteristics associated with geographical division of the threads into countries and content meta-summaries. The utilization of the mixed methods approach in innovation management research can be divided into several groups, in terms of the usage of those mixed methods in paper, which will be reflected in network analysis of collaboration between authors and in the analysis of co-occurrence and frequency.

\section{Discussion of the Results of Systematic Literature Review and Meta-Summary}

Application of mixed methods in research can open a new methodological approach for researchers. Numerous typologies and ordering of mixed methods have been proposed (Bryman 2007; Leech and Onwuegbuzie 2009), but in research studies the method that gives the best results (Bloch et al. 2014) is the typology proposed by Leech and Onwuegbuzie (2009). The advantage is in considering three dimensions in the proposed typology: degree of integration of mixed methods, their dependence over time and the weight assigned to individual methods. The first criterion indicates to what extent such elements of the research plan of a single research process, like the purpose of the research, the type of data and operations performed on it, the type of analysis and the type of inference performed, consider quantitative and qualitative methods. The second criterion is about whether different methods are used concurrently or sequentially in a study. The third criterion shows whether any of the methods in the study is dominant or whether they are treated complementarily.

Based on these criteria, eight types of mixed methods are distinguished in our article: (1) partially mixed complementary concurrent methods, (2) partly mixed dominant concurrent methods, (3) partly mixed complementary sequential methods, (4) partially mixed dominant sequential methods, (5) fully mixed complementary concurrent methods, (6) fully mixed dominant concurrent methods, (7) fully mixed complementary sequential methods, (8) fully mixed dominant sequential methods (Creswell and Clark 2017).

The partially mixed complementary concurrent methods approach occurs when the test plan provides for two phases of the study - quantitative and qualitative-implemented at the same time and their test results are given equal weight (Ahmadi and Osman 2020; Ghaben and Jaaron 2017; Birdthistle et al. 2016). An example of such a study (Birdthistle et al. 2016) explores the creation of realistic, engaging entrepreneurial competences among second-cycle students in the Republic of Ireland. The quantitative study concentrated on this case, on the comparison of student efficiency, in the case of teacher interactions with the Student Enterprise Awards (SEA) program in relation to the lack of access to a given program during the semester and at the end of it. The qualitative approach involved 29 partially structured interviews with teachers and nine school principals. This example illustrates the first type of mixed methods, because data were collected in parallel, and combinations 
of methods and results were made only at the last stage, when the data were collected and analyzed adequately using individual methods (qualitative and quantitative).

Partially mixed dominant concurrent methods occur when the plan research provides for two phases of research — quantitative and qualitative-implemented at the same time, the results of which are assigned different weights. An example is Hofmann (2015) research focusing on the question of who the companies should address in order to be able to make complex long-term decisions, come up with a vision and develop products and services that will appear on the market in a few years. A quantitative study to review existing concepts in this case had a smaller role than the qualitative study (questionnaire and interviews). Data collection and analysis were made prior to comparison and drew conclusions from the entire study.

Partially mixed complementary sequential methods occur when test phases using different methods follow one another and have the same weight in assessing test results. Based on the results of exploring the selected articles database (see Appendix A), seven authors used a given type of method (Yström et al. 2015; Jafarnejad et al. 2014; Siripongdee and Fongsuwan 2015; Barak and Usher 2019; Korneta 2019; Cortimiglia et al. 2016; Hoffmann 2011). An example of this variation of the mixed method is the article (Yström et al. 2015), which explored the creative climate in the open arena of innovation called SAFER, where 26 partner organizations meet to innovate together. First, a quantitative randomized study, i.e., a quantitative creative climate questionnaire, was conducted. The second phase of the study took place towards the end of the program and covered it and supplemented the data through interviews; the interviews were to reflect the perspective of the experience of group members related to the program. The analysis of the results of individual stages was made separately, and the combination was conducted only at the stage of data interpretation.

Partially mixed dominant sequential methods occur when one of the methods used in the sequential system is treated as more important in determining the results of the entire study. This type of method is very popular in our article database because it was used in 47 articles (Hankammer et al. 2019; Teixeira et al. 2019; Jensen 2011; Blindenbach-Driessen et al. 2010; Lagos and Kutsikos 2011; Radovanović et al. 2017; AI and Wu 2016a, 2016b; Bouette and Magee 2015; Teirlinck and Spithoven 2013; Walwyn et al. 2019; Almeida et al. 2019; Ghezzi 2019; Duarte and Pinho 2019; Burleson et al. 2019; van de Burgwal et al. 2019; Olsson et al. 2019; Harrison et al. 2018; Chasanidou et al. 2018; Reinhardt and Gurtner 2018; Ilonen et al. 2018; Al-edenat 2018; Holis et al. 2018; Geyskens et al. 2009; Cowell et al. 2018; Al-Husseini and Elbeltagi 2018; Tu 2018; Perenyi et al. 2018; Grimpe et al. 2017; Kılkış 2017; Bala and Venkatesh 2017; Lucas et al. 2016; Kopcha et al. 2016; Boerchers et al. 2016; Klingebiel and Joseph 2016; McCarthy et al. 2016; Swartz et al. 2016; Bakhshi et al. 2015; Udawatta et al. 2015; Timma et al. 2015; Owusu-Manu et al. 2015; (Maurice Khosa and Kalitanyi 2015; Flores Ituarte et al. 2018; Saunila 2017; Walravens 2015; Abubakar 2015; Dadfar et al. 2013; de Miranda Santo et al. 2006). Most often, the dominant method was the quantitative method used at the beginning of the study (in 25 articles), while in 22 the dominant method was the qualitative one. For example, authors (de Miranda Santo et al. 2006) in their study concentrated on analysis conducted by the Center for Management and Strategic Studies related to the research and development in nanotechnology to provide recommendations to the Brazilian government agencies on improving the competitiveness of selected sectors of the country's economy. The first stage—which was the dominant phase-involved data monitoring using text mining techniques. The second stage involved the use of quantitative methods to support the decision-making process related to establishing policies and activities. The next article concerned exploring utilization of the mobile city applications by citizens of Brussels, where the use of the iTunes App Store and Google Play applications was analyzed (Walravens 2015). Quantitative data was supplemented by qualitative interviews by experts with individuals in this field, such as city councilors, representatives of interest groups and developers.

Fully mixed complementary concurrent methods occur when a combination of different approaches-treated as equally important in assessing the result-is made on at least one of the elements of a single research process: determining the purpose of the study, choosing the type of data 
and activities performed, choosing the type of analysis or the type of inference. Different approaches are used in parallel at one or more stages of the research process. An example of this type of approach is the analysis of the nonscientific achievements of traditional disciplines and their reference citations in various disciplines (Corsi and Prencipe 2018). The study was based on the analysis of quantitative and qualitative results, which should already be considered a combination of these two types of approaches at the stage of determining the purpose of the study. This combination was also made at the data analysis and inference stage. The authors of two subsequent articles (Islam and Miyazaki 2009); (Crammond et al. 2018) also used this approach, using in their methods questionnaires with closed and open questions.

Fully mixed dominant concurrent methods occur when methods are combined in the scope of the elements of the research process-qualitative and quantitative, with one of them being treated as more important when determining the test result. Examples of such method combinations may be found in the following studies: (Hwang and Katayama 2009); (Kruger et al. 2018); (Kraus et al. 2018); (JosephNg 2018); (Kapasi and Grekova 2018) (Fu et al. 2018); (Ho et al. 2016); (Vicente-Oliva et al. 2016); (Hayter 2016); (Monsson and Jørgensen 2016). One of the mentioned articles was about examining students' perceptions and perspectives in relation to self-determination of learning in the context of entrepreneurial education (Kapasi and Grekova 2018). Data-both quantitative and qualitative-was obtained by means of a questionnaire and the combination of methods was made at the stage of determining the purpose of research, data analysis and conducted conclusions.

Similar research was performed in the study by Monsson and Jørgensen (2016). The authors presented differences in the characteristics of entrepreneurs, which influenced the benefits that resulted from various elements of the regional incubator program.

Fully mixed complementary sequential methods occur when a combination of different approaches is made on at least one element of the research process. Different approaches are used sequentially—one after another-at one or more stages of the research process, with both approaches given the same weight in determining the result of the study. Examples of this combination could be observed in the research conducted by Hu and McGrath (2011) and Hu and McGrath (2011). In the former, the potential utility of Maslow's theory in understanding technology adoption was examined. Initially, quantitative measures were considered, then these results were compared with the results obtained using a qualitative study. The second article describes a teacher development study related to the expansion of information and communication technologies (ICT) in the context of the national reform of English language teaching. Four groups of teachers were distinguished, considering quantitative measures of pedagogical effectiveness and sources of student success (external vs. internal). These groups were then compared with the received qualitative teacher study data.

Fully mixed dominant sequential methods and fully mixed complementary sequential methods occur in similar cases, but one approach is given greater weight in determining the final test result. An example of such a combination is research in 12 articles from the database (Imran and Gregor 2019; Lütjen et al. 2019; Shen 2019; Grimsby and Kure 2019; Yetis Larsson et al. 2019; Malan et al. 2019; Bican et al. 2017; Fellnhofer 2017a, 2017b; Thomas 2017; Berker and Throndsen.Throndsen 2017; O'Dwyer and Cormican 2017). One article (Bican et al. 2017) examined the way in which companies best manage knowledge through intellectual property rights in open innovation processes.

In the first phase of the study, qualitative methods (focus groups and interviews) were used, which provided information on the activities of the organizations studied. In the second, quantitative phase, a questionnaire was used which contained narrowed and more specifically targeted questions. In the last qualitative phase, focus groups were reused and the research focused on one topic-sources of customer satisfaction of this organization. The next phases of the study were planned based on data and results obtained in the preceding phase, and qualitative research was decisive in determining the results of the entire study.

Theoretical papers (Lecossier et al. 2019a, 2019b; Edling and Danks 2018; (McAdam and Debackere 2018; Guidice et al. 2016; Spiegel and Marxt 2015; Titarenko et al. 2014) were not included in our analysis. 
Regarding the conclusions derived from our study, several aspects may be emphasized. First, regarding the characteristics of identified articles with mixed methods, $92 \%$ of the entire database were empirical articles, and the most common purpose for using mixed methods in research on innovation management was development; the most common priority type was priority of quantity and quality. Additionally, sequential implementation of data collection was the most common implementation pattern used in the studied field.

The description of our dataset (out of 93 articles analyzed), shows that around a half of the analyzed articles $(50.54 \%$ ) use partially mixed dominant sequential methods, $12.90 \%$ fully mixed dominant sequential methods and $11.83 \%$ fully mixed dominant concurrent methods. As shown, partially mixed dominant sequential methods were common, as data were collected sequentially, initially with quantitative data gathering. The researchers believe that mixed methods have allowed the expansion of the statistical data interpretation because qualitative findings have helped to elaborate on the quantitative results in order to fully address the research questions and have profoundly elucidated the "real" phenomenon. Moreover, mixing the methods has also allowed a deeper examination of the research problem because qualitative methods were used to re-examine research questions, research objectives and the assumptions underlying each component proposed in the study. Mixed methods achieved two major goals related to theory verification and theory generation.

Second, the analysis of the number of studies of mixed methods in innovation management shows great variation year to year, and journal to journal. There is a clear growing trend in the publication of mixed methods research in innovation management in the case of the studied journals. Third, it can be indicated that it is very difficult to classify a given article into one area because various aspects are being described in many articles. The increase in publication from year to year may indicate that the topic is constantly being updated.

In the presentation of the meta-summary results, we begin with showing geographical coverage patterns of the articles analyzed in our study (Figure 5). Since authors from different countries cooperate with each other in order to obtain unambiguous results, we applied the lead author's affiliation as a determinant for the articles being discussed. Most of the studies included in our analysis have been conducted in the USA (10 papers), United Kingdom (7 papers), Germany (7 papers) and Australia (5 papers).

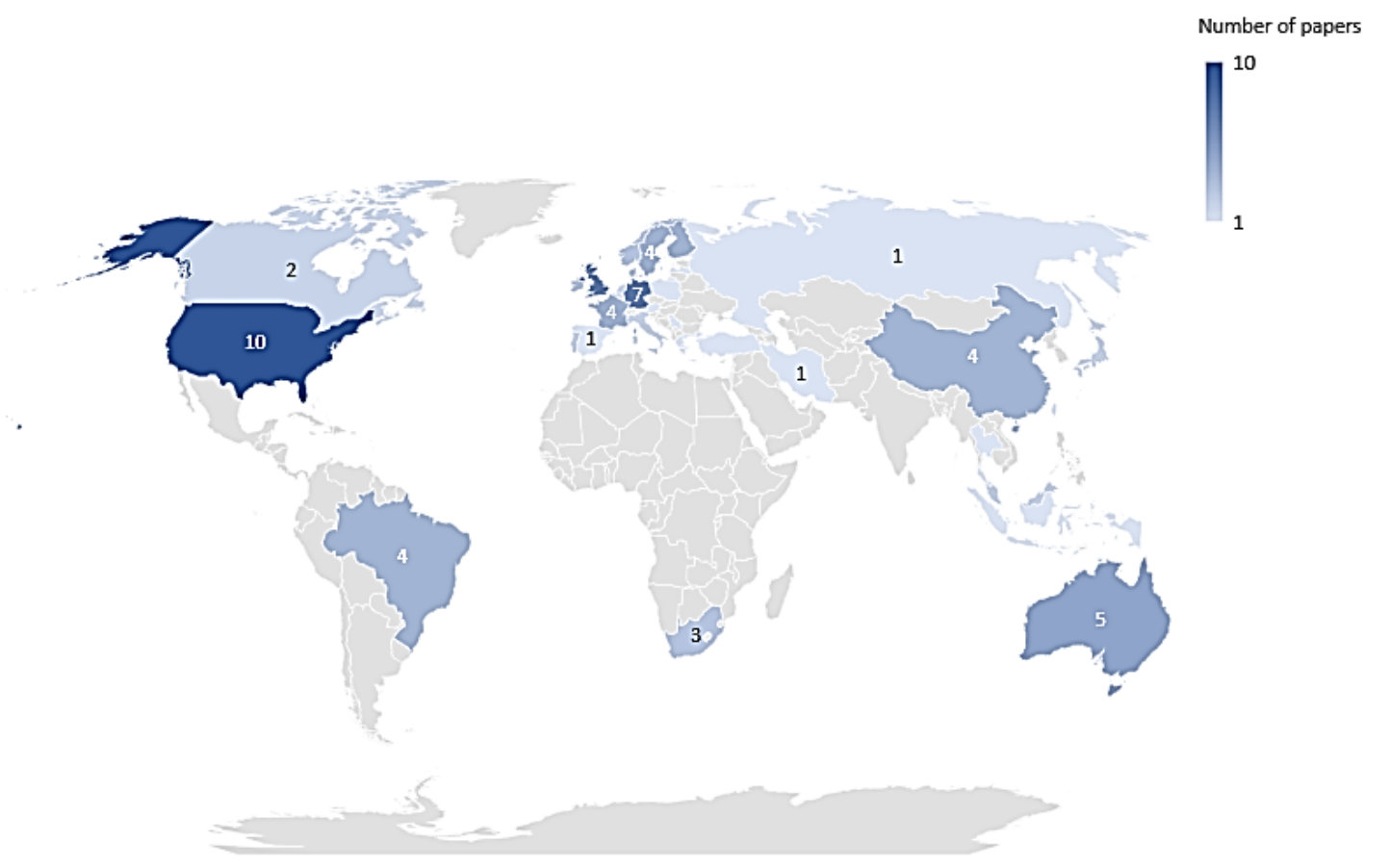

Figure 5. Frequency of the publication per country—by the lead author's affiliation (source: own study). 
The analysis of cooperation networks (Figure 6) between authors from different countries shows a high rate of cooperation of countries such as the USA, Germany, Denmark, Italy and the UK. Still, many researchers decide only to research with authors from their own country. It is evident that the network of connections of such clusters as Singapore and China does exist, and connections are paradoxically not obvious between Ireland and Belgium, despite obvious economic, cultural or geographic relations.
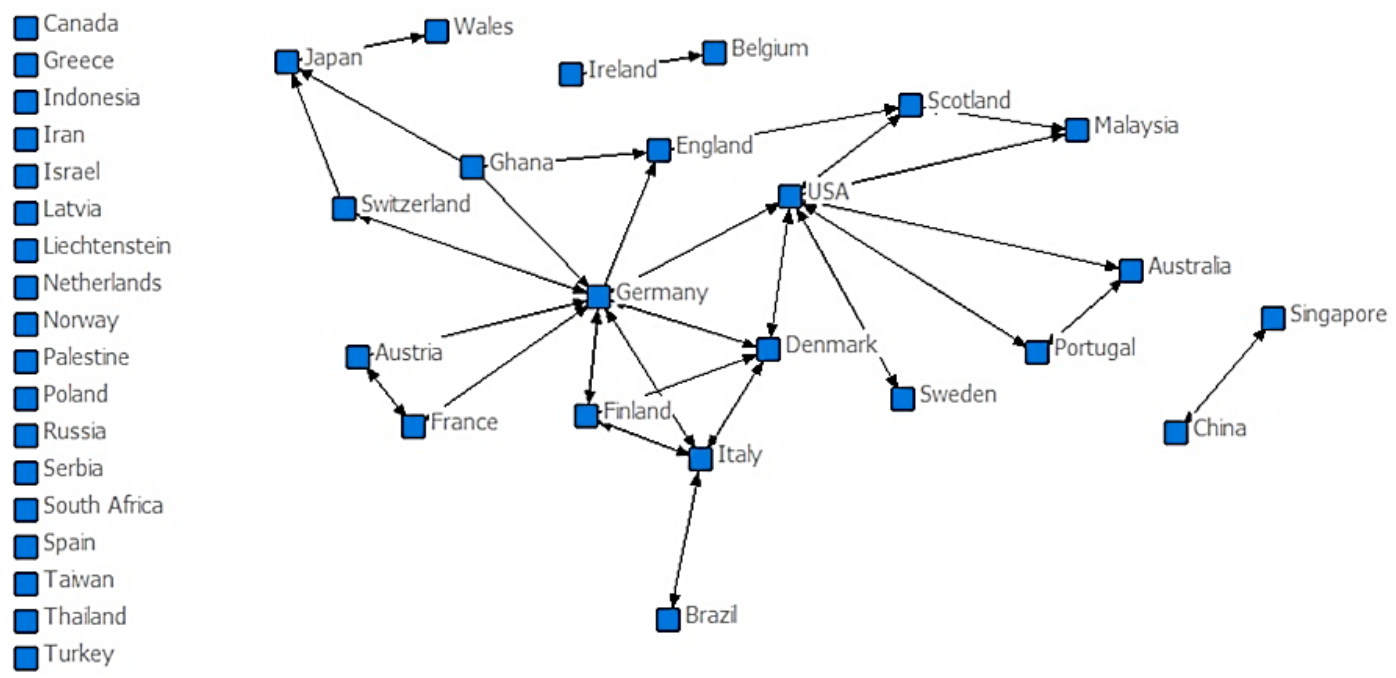

Figure 6. Network analysis of collaboration between authors (source: own study).

The bibliographic data from Scopus with an ris extension was converted to the .txt extension of plain-text format used by Web of Science with the Cite Space converter utility (Chen 2006). Then, based on these two files, a keywords co-occurrence network was created and analyzed with VOS viewer (van Eck and Waltman 2010). There were 871 unique keywords, 29 appeared at least 5 times, and this was chosen as a threshold for the research, to eliminate purely accidental and unrelated keywords. Three thematic clusters (see Figure 7) were formed.

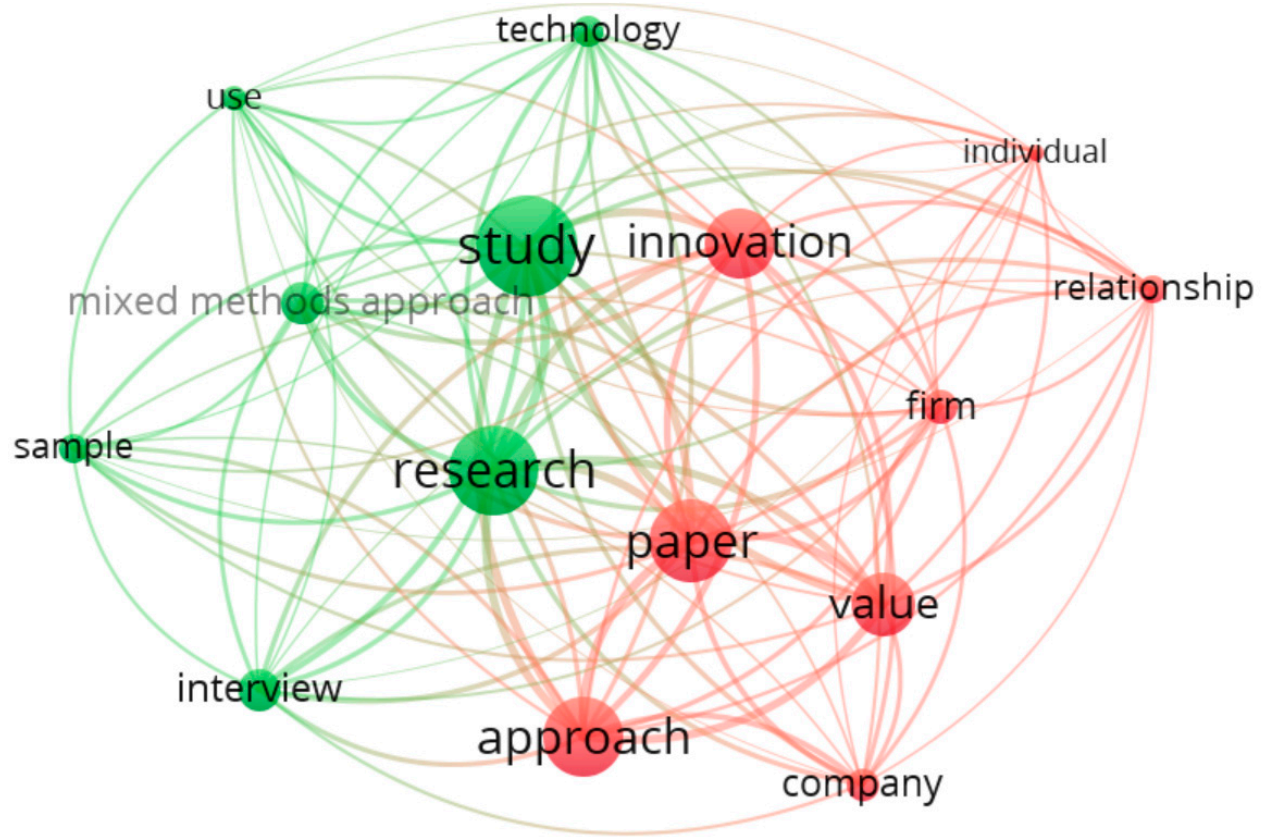

Figure 7. Keywords co-occurrence network with colored clusters, node size by number of occurrences (source: own study). 
Modularity of thematic network means that, apart from the central concepts that are obvious given the query types (mixed methods and innovation management), there are other research areas highly related to the scope of the query, like business, knowledge management, or countries such as the UK and USA. This outcome brings two additional conclusions. Firstly, it means that these identified areas should be subjected to additional, deepened literature analysis leading to better categorization of the related areas (clusters) of knowledge. Secondly, further analysis that would enhance understanding of this division's nature and explore social aspect of links is required to fully understand the leading authors, countries (USA and UK) and possible knowledge gaps.

\section{Conclusions}

Analysis using a mixed methods approach in innovation management research seems to be an interesting topic for academicians and practitioners because of its positive effects on organizational performance as well as growing interest in the subject of innovation and thus implementation in the culture of the organization. Companies seek to gain a competitive advantage by using innovation more effectively in enterprises.

Regardless of the increasing number of studies referring to mixed methods in innovation management research, there is a lack of studies that integrate and synthesize this body of knowledge. To advance our understanding of the various methods of innovation management, we carried out analyses of mixed methods in innovation management and we presented the results using figures. The results contained will be useful to scientists interested in using individual methods in research and using them in research. Additionally, this study offers a good starting point for future research to do more thorough research into the given method.

This study reported on the characteristic of mixed methods in innovation management research present in the existing literature. Regardless of the increased number of studies referring to this topic, there is a lack of review of this body of knowledge. This study answers a call by Cameron and Molina-Azorin (2011) and Cameron and Molina-Azorin (2011) for a systematic literature review. In addition, consistent with recent recommendations to develop an advanced standard of methodological rigor of reviews of the management literature (Newbert 2007), we analyzed 93 articles published in seventy-one academic journals using a systematic literature review approach. Our paper is a compendium of knowledge in the field of mixed methods in innovation management that analyzes the most important publications in a given field published in the Web of Science and Scopus databases.

Based on the literature review, it can be concluded that some studies reveal conflicting findings regarding the use of mismatched methods in the innovation management literature, which makes it difficult to draw general conclusions. Some authors believe that it is worth starting their research by conducting partially mixed dominant sequential methods.

As Mason (Mason 2006) indicated, mixing methods offers enormous potential for exploring new dimensions. The predominance of more quantitative-based methodological tools in innovation management research does not mean that these tools are applicable to all research questions. The research question and context should dictate the choice of the appropriate research methods. We would like to indicate that the knowledge about mixed methods research can stimulate a researcher to better define and analyze innovative problems and research questions in innovation management research. Hopefully, this review of management empirical studies which have used mixed methods designs along with the ideas offered for the application of mixed methods studies may favor progress on innovation management research.

Some limitations of our research should be explicated. One limitation of this study to mention is the selection of the articles, since some papers may have not been included due to missing keywords or owing to the fact that articles have not been included in the search in the two chosen databases. We only included peer reviewed journal articles in our study and excluded books and conference proceedings. Moreover, excluding unpublished articles may introduce a bias into the effect size of our result. While such an issue is common in most meta-summaries (Sandelowski and Barroso 2003) our 
result should be interpreted with caution. In our view, extensive searches into two databases illustrate the current state of research into mixed methods in innovation management. Nevertheless, future research on a given topic may show the phenomenon in a different way due to the inclusion of other databases and the inclusion of unpublished research.

Finally, regarding future research, although the current study attempts to extend the knowledge of the application of mixed methods research in management research, much remains to be learned. For example, it would be interesting to analyze the yield from mixed methods studies regarding the added value of these articles, or the contribution to the improvement of several methodological aspects such as validity or construct measurement. Moreover, an analysis of the use and application of mixed methods research in other organizational and management fields would also be interesting and could expand upon the research reported here. Further research is also required to develop a deeper understanding of the relationship between the element of commitment and innovation performance improvement. For this purpose, it is worth exploring the management of relationships between enterprises for sustainable social development and examining the impact of the buyer-supplier relationship in terms of innovation (Awan 2019; Awan et al. 2018).

Additionally, thanks to future application of bibliometric analysis and cluster analysis of the co-citation analysis, studies could offer a comprehensive and up-to-date identification and assessment of trends in mixed methods utilization in innovation management research.

Author Contributions: These authors contributed equally to this work. Conceptualization, K.B. and M.S.; Data curation, M.S.; Formal analysis, K.B. and M.S.; Funding acquisition, K.B. and M.S.; Investigation, K.B.; Methodology, K.B.; Supervision, M.S.; Visualization, K.B.; Writing—original draft, K.B.; Writing—review \& editing, M.S. All authors have read and agreed to the published version of the manuscript.

Funding: This research was partly supported by the funds allocated to the College of Management Sciences and Quality of the Cracow University of Economics in the framework of grants for maintaining research potential (grant number 73/ZZA/2020/POT) and the APC was funded by the subsidies granted to the Cracow University of Economics (grant number 98/SD/2020/PRO).

Conflicts of Interest: The authors declare no conflict of interest. The funders had no role in the design of the study; in the collection, analyses, or interpretation of data; in the writing of the manuscript, or in the decision to publish the results.

\section{Appendix A}

List of articles included for literature review by year (source: own study)

\begin{tabular}{llcc}
\hline Source Title & Authors & Year & Cited by \\
\hline $\begin{array}{l}\text { International Journal of Business } \\
\text { Innovation and Research }\end{array}$ & Ahmadi M., Osman M.H.M. & 2020 & 0 \\
\hline $\begin{array}{l}\text { INTERNATIONAL JOURNAL OF } \\
\text { INNOVATION SCIENCE }\end{array}$ & $\begin{array}{l}\text { Almeida, Fernando; Kennedy, Andrew } \\
\text { John; Lin, Brook; Nowak, Irina V. }\end{array}$ & 2019 & 0 \\
\hline COMPUTERS \& EDUCATION & Barak, Miri; Usher, Maya & 2019 & 3 \\
\hline ENERGY RESEARCH \& SOCIAL SCIENCE & $\begin{array}{l}\text { Burleson, Grace; Tilt, Bryan; Sharp, } \\
\text { Kendra; MacCarty, Nordica }\end{array}$ & 2019 & 0 \\
\hline JOURNAL OF BUSINESS RESEARCH & Duarte, Paulo; Pinho, Jose Carlos & 2019 & 3 \\
\hline $\begin{array}{l}\text { TECHNOLOGICAL FORECASTING AND } \\
\text { SOCIAL CHANGE }\end{array}$ & $\begin{array}{l}\text { Ghezzi, Antonio } \\
\text { BRITISH FOOD JOURNAL }\end{array}$ & $\begin{array}{l}\text { Grimsby, Sveinung; Kure, } \\
\text { Cathrine Finne }\end{array}$ \\
\hline Journal of Cleaner Production & $\begin{array}{l}\text { Hankammer S., Brenk S., Fabry H., } \\
\text { Nordemann A., Piller F.T. }\end{array}$ & 2019 \\
\hline
\end{tabular}




\begin{tabular}{|c|c|c|c|}
\hline Source Title & Authors & Year & Cited by \\
\hline $\begin{array}{l}\text { INFORMATION } \\
\text { TECHNOLOGY \& PEOPLE }\end{array}$ & Imran, Ahmed; Gregor, Shirley & 2019 & 0 \\
\hline BRITISH FOOD JOURNAL & Korneta, Piotr & 2019 & 0 \\
\hline INFORMATION AND ORGANIZATION & $\begin{array}{l}\text { Larsson, Zeynep Yetis; Di Gangi, } \\
\text { Paul M.; Teigland, Robin }\end{array}$ & 2019 & 1 \\
\hline $\begin{array}{l}\text { International Journal of Services Operations } \\
\text { and Informatics }\end{array}$ & $\begin{array}{l}\text { Lecossier A., Pallot M., Crubleau P., } \\
\text { Richir S. }\end{array}$ & 2019 & 2 \\
\hline $\begin{array}{l}\text { AI EDAM-ARTIFICIAL INTELLIGENCE } \\
\text { FOR ENGINEERING DESIGN ANALYSIS } \\
\text { AND MANUFACTURING }\end{array}$ & $\begin{array}{l}\text { Lecossier, Adrien; Pallot, Marc; } \\
\text { Crubleau, Pascal; Richir, Simon }\end{array}$ & 2019 & 0 \\
\hline JOURNAL OF BUSINESS RESEARCH & $\begin{array}{l}\text { Luetjen, Heiner; Schultz, Carsten; } \\
\text { Tietze, Frank; Urmetzer, Florian }\end{array}$ & 2019 & 0 \\
\hline $\begin{array}{l}\text { INTERNATIONAL REVIEW OF RETAIL } \\
\text { DISTRIBUTION AND } \\
\text { CONSUMER RESEARCH }\end{array}$ & $\begin{array}{l}\text { Olsson, Annika; Paredes, Karla Marie B.; } \\
\text { Johansson, Ulf; Roese, Malin Olander; } \\
\text { Ritzen, Sofia }\end{array}$ & 2019 & 0 \\
\hline $\begin{array}{l}\text { JOURNAL OF THE ASSOCIATION FOR } \\
\text { INFORMATION SCIENCE } \\
\text { AND TECHNOLOGY }\end{array}$ & Shen, Yi & 2019 & 0 \\
\hline Management Research Review & Teixeira E.K., Oliveira M., Curado C. & 2019 & 0 \\
\hline JOURNAL OF TECHNOLOGY TRANSFER & $\begin{array}{l}\text { van de Burgwal, Linda H. M.; Dias, Ana; } \\
\text { Claassen, Eric }\end{array}$ & 2019 & 0 \\
\hline $\begin{array}{l}\text { INTERNATIONAL JOURNAL OF } \\
\text { TECHNOLOGY MANAGEMENT }\end{array}$ & $\begin{array}{l}\text { Vlok, Awie; Ungerer, Marius; } \\
\text { Malan, Johan }\end{array}$ & 2019 & 0 \\
\hline $\begin{array}{l}\text { JOURNAL OF MANUFACTURING } \\
\text { TECHNOLOGY MANAGEMENT }\end{array}$ & $\begin{array}{l}\text { Walwyn, David; Bertoldi, Andreas; } \\
\text { Gable, Christian }\end{array}$ & 2019 & 1 \\
\hline $\begin{array}{l}\text { JOURNAL OF ORGANIZATIONAL } \\
\text { CHANGE MANAGEMENT }\end{array}$ & Al-edenat, Malek & 2018 & 3 \\
\hline $\begin{array}{l}\text { INNOVATIONS IN EDUCATION AND } \\
\text { TEACHING INTERNATIONAL }\end{array}$ & Al-Husseini, Sawasn; Elbeltagi, Ibrahim & 2018 & 0 \\
\hline $\begin{array}{l}\text { CREATIVITY AND INNOVATION } \\
\text { MANAGEMENT }\end{array}$ & $\begin{array}{l}\text { Chasanidou, Dimitra; Sivertstol, Njal; } \\
\text { Hildrum, Jarle }\end{array}$ & 2018 & 0 \\
\hline $\begin{array}{l}\text { INTERNATIONAL JOURNAL OF } \\
\text { ENTREPRENEURIAL VENTURING }\end{array}$ & Corsi, Christian; Prencipe, Antonio & 2018 & 0 \\
\hline $\begin{array}{l}\text { JOURNAL OF ENTERPRISING } \\
\text { COMMUNITIES-PEOPLE AND PLACES } \\
\text { IN THE GLOBAL ECONOMY }\end{array}$ & $\begin{array}{l}\text { Cowell, Margaret; Lyon-Hill, Sarah; } \\
\text { Tate, Scott }\end{array}$ & 2018 & 3 \\
\hline BALTIC JOURNAL OF MANAGEMENT & $\begin{array}{l}\text { Crammond, Robert; Omeihe, Kingsley } \\
\text { Obi; Murray, Alan; Ledger, Kirstin }\end{array}$ & 2018 & 1 \\
\hline ENERGY RESEARCH \& SOCIAL SCIENCE & Edling, Laura; Danks, Cecilia & 2018 & 1 \\
\hline $\begin{array}{l}\text { LEADERSHIP \& ORGANIZATION } \\
\text { DEVELOPMENT JOURNAL }\end{array}$ & Fu, Lihua; Liu, Zhiying; Liao, Suqin & 2018 & 1 \\
\hline $\begin{array}{l}\text { ASIA PACIFIC JOURNAL } \\
\text { OF MANAGEMENT }\end{array}$ & $\begin{array}{l}\text { Harrison, Richard; Scheela, William; Lai, } \\
\text { P. C.; Vivekarajah, Sivapalan }\end{array}$ & 2018 & 3 \\
\hline
\end{tabular}




\begin{tabular}{|c|c|c|c|}
\hline Source Title & Authors & Year & Cited by \\
\hline $\begin{array}{l}\text { 1ST ITB CENTENNIAL AND 4TH } \\
\text { PLANOCOSMO INTERNATIONAL } \\
\text { CONFERENCE }\end{array}$ & Holis, Y. M.; Syabri, I.; Prabatmojo, H. & 2018 & 0 \\
\hline $\begin{array}{l}\text { INTERNATIONAL JOURNAL OF } \\
\text { ENTREPRENEURIAL } \\
\text { BEHAVIOUR \& RESEARCH }\end{array}$ & $\begin{array}{l}\text { Ilonen, Sanna; Heinonen, Jarna; } \\
\text { Stenholm, Pekka }\end{array}$ & 2018 & 5 \\
\hline RAPID PROTOTYPING JOURNAL & $\begin{array}{l}\text { Ituarte, Inigo Flores; Chekurov, Sergei; } \\
\text { Tuomi, Jukka; Mascolo, Julien Etienne; } \\
\text { Zanella, Alessandro; Springer, Patrick; } \\
\text { Partanen, Jouni }\end{array}$ & 2018 & 3 \\
\hline $\begin{array}{l}\text { TECHNOLOGICAL FORECASTING AND } \\
\text { SOCIAL CHANGE }\end{array}$ & JosephNg, P. S. & 2018 & 1 \\
\hline EDUCATION AND TRAINING & Kapasi, Isla; Grekova, Galina & 2018 & 3 \\
\hline JOURNAL OF BUSINESS RESEARCH & $\begin{array}{l}\text { Kraus, Sascha; Kallmuenzer, Andreas; } \\
\text { Stieger, Daniel; Peters, Mike; } \\
\text { Calabro, Andrea }\end{array}$ & 2018 & 5 \\
\hline JOURNAL OF CLEANER PRODUCTION & $\begin{array}{l}\text { Kruger, Claudia; Gusmao Caiado, } \\
\text { Rodrigo Goyannes; Braga Franca, Sergio } \\
\text { Luiz; Goncalves Quelhas, Osvaldo Luiz }\end{array}$ & 2018 & 6 \\
\hline R \& D MANAGEMENT & McAdam, Maura; Debackere, Koenraad & 2018 & 10 \\
\hline $\begin{array}{l}\text { INTERNATIONAL JOURNAL OF } \\
\text { ENTREPRENEURIAL } \\
\text { BEHAVIOUR \& RESEARCH }\end{array}$ & $\begin{array}{l}\text { Perenyi, Aron; Zolin, Roxanne; Maritz, } \\
\text { Alex }\end{array}$ & 2018 & 8 \\
\hline $\begin{array}{l}\text { TECHNOLOGICAL FORECASTING AND } \\
\text { SOCIAL CHANGE }\end{array}$ & Reinhardt, Ronny; Gurtner, Sebastian & 2018 & 3 \\
\hline $\begin{array}{l}\text { INTERNATIONAL JOURNAL OF } \\
\text { LOGISTICS MANAGEMENT }\end{array}$ & $\mathrm{Tu}$, Mengru & 2018 & 10 \\
\hline $\begin{array}{l}\text { BUSINESS PROCESS } \\
\text { MANAGEMENT JOURNAL }\end{array}$ & Bala, Hillol; Venkatesh, Viswanath & 2017 & 2 \\
\hline $\begin{array}{l}\text { JOURNAL OF ENVIRONMENTAL } \\
\text { POLICY \& PLANNING }\end{array}$ & Berker, Thomas; Throndsen, William & 2017 & 1 \\
\hline $\begin{array}{l}\text { JOURNAL OF } \\
\text { KNOWLEDGE MANAGEMENT }\end{array}$ & $\begin{array}{l}\text { Bican, Peter M.; Guderian, Carsten C.; } \\
\text { Ringbeck, Anne }\end{array}$ & 2017 & 12 \\
\hline $\begin{array}{l}\text { INTERNATIONAL JOURNAL OF } \\
\text { KNOWLEDGE-BASED DEVELOPMENT }\end{array}$ & Fellnhofer, Katharina & 2017 & 2 \\
\hline $\begin{array}{l}\text { JOURNAL FOR INTERNATIONAL } \\
\text { BUSINESS AND } \\
\text { ENTREPRENEURSHIP DEVELOPMENT }\end{array}$ & Fellnhofer, Katharina & 2017 & 0 \\
\hline $\begin{array}{l}\text { International Journal of Project } \\
\text { Organisation and Management }\end{array}$ & Ghaben R.K., Jaaron A.A.M. & 2017 & 2 \\
\hline $\begin{array}{l}\text { JOURNAL OF PRODUCT } \\
\text { INNOVATION MANAGEMENT }\end{array}$ & $\begin{array}{l}\text { Grimpe, Christoph; Sofka, Wolfgang; } \\
\text { Bhargava, Mukesh; Chatterjee, Rabikar }\end{array}$ & 2017 & 9 \\
\hline $\begin{array}{l}\text { MANAGEMENT OF } \\
\text { ENVIRONMENTAL QUALITY }\end{array}$ & Kilkis, Siir & 2017 & 0 \\
\hline
\end{tabular}




\begin{tabular}{|c|c|c|c|}
\hline Source Title & Authors & Year & Cited by \\
\hline $\begin{array}{l}\text { Journal of technology } \\
\text { management \& innovation }\end{array}$ & O’Dwyer, Clare; Cormican, Kathryn & 2017 & 1 \\
\hline $\begin{array}{l}\text { ENTREPRENEURIAL BUSINESS AND } \\
\text { ECONOMICS REVIEW }\end{array}$ & $\begin{array}{l}\text { Radovanovic, Nikola; Dmitrovic, Veljko; } \\
\text { Joksimovic, Nevenka Zarkic }\end{array}$ & 2017 & 1 \\
\hline MEASURING BUSINESS EXCELLENCE & Saunila, Minna & 2017 & 6 \\
\hline $\begin{array}{l}\text { BUSINESS PROCESS } \\
\text { MANAGEMENT JOURNAL }\end{array}$ & Thomas, Ashish & 2017 & 0 \\
\hline $\begin{array}{l}\text { INDUSTRIAL } \\
\text { MANAGEMENT \& DATA SYSTEMS }\end{array}$ & Ai, Chi-Han; Wu, Hung-Che & 2016 & 2 \\
\hline $\begin{array}{l}\text { JOURNAL OF ORGANIZATIONAL } \\
\text { CHANGE MANAGEMENT }\end{array}$ & Ai, Chi-Han; Wu, Hung-Che & 2016 & 5 \\
\hline EDUCATION AND TRAINING & $\begin{array}{l}\text { Birdthistle, Naomi; Costin, Yvonne; } \\
\text { Hynes, Briga }\end{array}$ & 2016 & 3 \\
\hline $\begin{array}{l}\text { EXTRACTIVE INDUSTRIES AND } \\
\text { SOCIETY-AN } \\
\text { INTERNATIONAL JOURNAL }\end{array}$ & $\begin{array}{l}\text { Boerchers, Morrissa; Fitzpatrick, } \\
\text { Patricia; Storie, Christopher; } \\
\text { Hostetler, Glen }\end{array}$ & 2016 & 3 \\
\hline R \& D MANAGEMENT & $\begin{array}{l}\text { Cortimiglia, Marcelo Nogueira; Ghezzi, } \\
\text { Antonio; Frank, Alejandro German }\end{array}$ & 2016 & 35 \\
\hline JOURNAL OF BUSINESS RESEARCH & $\begin{array}{l}\text { Guidice, Rebecca M.; Mero, Neal P.; } \\
\text { Matthews, Lucy M.; Greene, Juanne V. }\end{array}$ & 2016 & 6 \\
\hline RESEARCH POLICY & Hayter, Christopher S. & 2016 & 43 \\
\hline TECHNOVATION & $\begin{array}{l}\text { Ho, Yuen-Ping; Ruan, Yi; Hang, } \\
\text { Chang-Chieh; Wong, Poh-Kam }\end{array}$ & 2016 & 8 \\
\hline STRATEGIC MANAGEMENT JOURNAL & Klingebiel, Ronald; Joseph, John & 2016 & 14 \\
\hline $\begin{array}{l}\text { BRITISH JOURNAL OF } \\
\text { EDUCATIONAL TECHNOLOGY }\end{array}$ & $\begin{array}{l}\text { Kopcha, Theodore J.; Rieber, Lloyd P.; } \\
\text { Walker, Brandy B. }\end{array}$ & 2016 & 5 \\
\hline $\begin{array}{l}\text { IEEE TRANSACTIONS ON } \\
\text { PROFESSIONAL COMMUNICATION }\end{array}$ & $\begin{array}{l}\text { Lucas, Kristen; Kerrick, Sharon A.; } \\
\text { Haugen, Jenna; Crider, Cole J. }\end{array}$ & 2016 & 3 \\
\hline BRITISH FOOD JOURNAL & $\begin{array}{l}\text { McCarthy, Breda; Liu, Hong-Bo; } \\
\text { Chen, Tingzhen }\end{array}$ & 2016 & 17 \\
\hline $\begin{array}{l}\text { JOURNAL OF SMALL BUSINESS AND } \\
\text { ENTERPRISE DEVELOPMENT }\end{array}$ & $\begin{array}{l}\text { Monsson, Christian Kjaer; } \\
\text { Jorgensen, Soren Berg }\end{array}$ & 2016 & 8 \\
\hline $\begin{array}{l}\text { INDUSTRIAL MARKETING } \\
\text { MANAGEMENT }\end{array}$ & $\begin{array}{l}\text { Purchase, Sharon; Kum, Christina; } \\
\text { Olaru, Doina }\end{array}$ & 2016 & 4 \\
\hline $\begin{array}{l}\text { INTERNATIONAL JOURNAL OF } \\
\text { GENDER AND ENTREPRENEURSHIP }\end{array}$ & $\begin{array}{l}\text { Swartz, Ethne; Amatucci, Frances M.; } \\
\text { Coleman, Susan }\end{array}$ & 2016 & 0 \\
\hline $\begin{array}{l}\text { INTERNATIONAL JOURNAL OF } \\
\text { INNOVATION MANAGEMENT }\end{array}$ & $\begin{array}{l}\text { Vicente-Oliva, Silvia; Martinez-Sanchez, } \\
\text { Angel; Berges-Muro, Luis }\end{array}$ & 2016 & 0 \\
\hline $\begin{array}{l}\text { WORLD JOURNAL OF } \\
\text { ENTREPRENEURSHIP MANAGEMENT } \\
\text { AND SUSTAINABLE DEVELOPMENT }\end{array}$ & Abubakar, Habib Auwal & 2015 & 3 \\
\hline
\end{tabular}




\begin{tabular}{|c|c|c|c|}
\hline Source Title & Authors & Year & Cited by \\
\hline RESEARCH POLICY & $\begin{array}{l}\text { Bakhshi, Hasan; Edwards, John S.; } \\
\text { Roper, Stephen; Scully, Judy; Shaw, } \\
\text { Duncan; Morley, Lorraine; } \\
\text { Rathbone, Nicola }\end{array}$ & 2015 & 7 \\
\hline $\begin{array}{l}\text { JOURNAL OF SMALL BUSINESS AND } \\
\text { ENTERPRISE DEVELOPMENT }\end{array}$ & Bouette, Martin; Magee, Florence & 2015 & 6 \\
\hline $\begin{array}{l}\text { TECHNOLOGICAL FORECASTING AND } \\
\text { SOCIAL CHANGE }\end{array}$ & Hofmann, Rupert & 2015 & 7 \\
\hline $\begin{array}{l}\text { JOURNAL OF ENTERPRISING } \\
\text { COMMUNITIES-PEOPLE AND PLACES } \\
\text { IN THE GLOBAL ECONOMY }\end{array}$ & $\begin{array}{l}\text { Khosa, Risimati Maurice; Kalitanyi, } \\
\text { Vivence }\end{array}$ & 2015 & 10 \\
\hline $\begin{array}{l}\text { JOURNAL OF ENGINEERING DESIGN } \\
\text { AND TECHNOLOGY }\end{array}$ & $\begin{array}{l}\text { Owusu-Manu, D.; Quaigrain, R.; } \\
\text { Edwards, D. J. }\end{array}$ & 2015 & 1 \\
\hline $\begin{array}{l}\text { ENGINEERING CONSTRUCTION AND } \\
\text { ARCHITECTURAL MANAGEMENT }\end{array}$ & Singh, Vishal; Holmstrom, Jan & 2015 & 14 \\
\hline Research Journal of Business Management & Siripongdee S., Fongsuwan W. & 2015 & 2 \\
\hline $\begin{array}{l}\text { INTERNATIONAL JOURNAL OF } \\
\text { ENTREPRENEURIAL VENTURING }\end{array}$ & Spiegel, Markus; Marxt, Christian & 2015 & 0 \\
\hline $\begin{array}{l}\text { INTERNATIONAL SCIENTIFIC } \\
\text { CONFERENCE ENVIRONMENTAL AND } \\
\text { CLIMATE TECHNOLOGIES, } \\
\text { CONECT } 2014\end{array}$ & $\begin{array}{l}\text { Timma, Lelde; Blumberga, Andra; } \\
\text { Blumberga, Dagnija }\end{array}$ & 2015 & 2 \\
\hline $\begin{array}{l}\text { RESOURCES CONSERVATION } \\
\text { AND RECYCLING }\end{array}$ & $\begin{array}{l}\text { Udawatta, Nilupa; Zuo, Jian; Chiveralls, } \\
\text { Keri; Zillante, George }\end{array}$ & 2015 & 41 \\
\hline TELEMATICS AND INFORMATICS & Walravens, Nils & 2015 & 32 \\
\hline $\begin{array}{l}\text { European Journal of Innovation } \\
\text { Management }\end{array}$ & Yström A., Aspenberg H., Kumlin A. & 2015 & 5 \\
\hline $\begin{array}{l}\text { Research Journal of Applied Sciences, } \\
\text { Engineering and Technology }\end{array}$ & $\begin{array}{l}\text { Jafarnejad A., Mohaghar A., } \\
\text { Manteghi M., Yasaei M. }\end{array}$ & 2014 & 0 \\
\hline $\begin{array}{l}\text { PROGRESS IN INDUSTRIAL AND CIVIL } \\
\text { ENGINEERING III, PT } 1\end{array}$ & Titarenko, B.; Titov, S.; Titarenko, R. & 2014 & 5 \\
\hline $\begin{array}{l}\text { TOTAL QUALITY MANAGEMENT \& } \\
\text { BUSINESS EXCELLENCE }\end{array}$ & $\begin{array}{l}\text { Dadfar, Hossein; Dahlgaard, Jens J.; } \\
\text { Brege, Staffan; Alamirhoor, Amir }\end{array}$ & 2013 & 23 \\
\hline R \& D MANAGEMENT & Teirlinck, Peter; Spithoven, Andre & 2013 & 19 \\
\hline EUROPEAN JOURNAL OF MARKETING & Hoffmann, Stefan & 2011 & 18 \\
\hline $\begin{array}{l}\text { TECHNOLOGY PEDAGOGY } \\
\text { AND EDUCATION }\end{array}$ & Hu, Zhiwen; McGrath, Ian & 2011 & 18 \\
\hline $\begin{array}{l}\text { International Journal of Knowledge, } \\
\text { Culture and Change Management }\end{array}$ & Jensen K.R. & 2011 & 2 \\
\hline European Research Studies Journal & Lagos D., Kutsikos K. & 2011 & 1 \\
\hline
\end{tabular}




\begin{tabular}{llcc}
\hline Source Title & Authors & Year & Cited by \\
\hline $\begin{array}{l}\text { Journal of Product Innovation Management } \\
\text { International Journal of } \\
\text { Production Research }\end{array}$ & $\begin{array}{l}\text { Blindenbach-Driessen F., Van Dalen J., } \\
\text { Van Den Ende J. }\end{array}$ & 2010 & 52 \\
\hline SCIENCE AND PUBLIC POLICY & Hwang R., Katayama H. & 2009 & 57 \\
\hline $\begin{array}{l}\text { TECHNOLOGICAL FORECASTING AND } \\
\text { SOCIAL CHANGE }\end{array}$ & $\begin{array}{l}\text { Sslam, Nazrul; Miyazaki, Kumiko } \\
\text { Gilda Massari; dos Santos, Dalci Maria; } \\
\text { Filho, Lelio Fellows }\end{array}$ & 2006 & 2009 \\
\hline
\end{tabular}

\section{References}

Abubakar, Habib Auwal. 2015. Entrepreneurship development and financial literacy in Africa. World Journal of Entrepreneurship, Management and Sustainable Development 11: 281-94. [CrossRef]

Ahmadi, Meghdad, and Mohd Hassan Mohd Osman. 2020. Exploitative dominant balanced ambidexterity solving the paradox of innovation strategies in SMEs. International Journal of Business Innovation and Research 21: 79-107. [CrossRef]

AI, Chi Han, and Hung Che Wu. 2016a. Benefiting from external knowledge? A study of telecommunications industry cluster in Shenzhen, China. Industrial Management and Data Systems 116: 622-45. [CrossRef]

AI, Chi Han, and Hung Che Wu. 2016b. Where does the source of external knowledge come from? A case of the Shanghai ICT chip industrial cluster in China. Journal of Organizational Change Management 29: 150-75. [CrossRef]

Al-edenat, Malek. 2018. Reinforcing innovation through transformational leadership: Mediating role of job satisfaction. Journal of Organizational Change Management 31: 810-38. [CrossRef]

Al-Husseini, Sawasn, and Ibrahim Elbeltagi. 2018. The role of knowledge sharing in enhancing innovation: A comparative study of public and private higher education institutions in Iraq. Innovations in Education and Teaching International 55: 23-33. [CrossRef]

Aliaga-Isla, Rocío, and Alex Rialp. 2013. Systematic review of immigrant entrepreneurship literature: Previous findings and ways forward. Entrepreneurship \& Regional Development 25: 819-44. [CrossRef]

Almeida, Fernando, Andrew John Kennedy, Brook Lin, and Irina V. Nowak. 2019. Measuring innovation through a crowd source initiative. International Journal of Innovation Science 11: 471-88. [CrossRef]

Awan, Usama. 2019. Effects of buyer-supplier relationship on social performance improvement and innovation performance improvement. International Journal of Applied Management Science 11: 21-35. [CrossRef]

Awan, Usama. 2020. Industrial Ecology in Support of Sustainable Development Goals. In Responsible Consumption and Production, Encyclopedia of the UN Sustainable Development Goals. Edited by W. Leal Filho, A. Azul, L. Brandli, P. Özuyar and T. Wall. Cham: Springer. [CrossRef]

Awan, Usama, Andrzej Kraslawski, and Janne Huiskonen. 2018. Governing interfirm relationships for social sustainability: The relationship between governance mechanisms, sustainable collaboration, and cultural intelligence. Sustainability 10: 4473. [CrossRef]

Awan, Usama, Robert Sroufe, and Andrzej Kraslawski. 2019. Creativity enables sustainable development: Supplier engagement as a boundary condition for the positive effect on green innovation. Journal of Cleaner Production 226: 172-85. [CrossRef]

Bakhshi, Hasan, John S. Edwards, Stephen Roper, Judy Scully, Duncan Shaw, Lorraine Morley, and Nicola Rathbone. 2015. Assessing an experimental approach to industrial policy evaluation: Applying RCT+ to the case of Creative Credits. Research Policy 44: 1462-72. [CrossRef]

Bala, Hillol, and Viswanath Venkatesh. 2017. Employees' reactions to IT-enabled process innovations in the age of data analytics in healthcare. Business Process Management Journal 23: 671-702. [CrossRef]

Barak, Miri, and Maya Usher. 2019. The innovation profile of nanotechnology team projects of face-to-face and online learners. Computers and Education 137: 1-11. [CrossRef]

Bazeley, Pat. 2015. Mixed methods in management research: Implications for the field. Electronic Journal of Business Research Methods 13: 27-35. 
Berker, Thomas, and William Throndsen.Throndsen. 2017. Planning story lines in smart grid road maps (2010-2014): Three types of maps for coordinated time travel. Journal of Environmental Policy and Planning 19: 214-28. [CrossRef]

Berry, Michael, and Jacob Kogan. 2010. Text Mining: Applications and Theory, Text. New York: Wiley. [CrossRef] Bican, Peter M., Carsten C. Guderian, and Anne Ringbeck. 2017. Managing knowledge in open innovation processes: An intellectual property perspective. Journal of Knowledge Management 21: 1384-405. [CrossRef]

Birdthistle, Naomi, Yvonne Costin, and Briga Hynes. 2016. Engendering entrepreneurial competencies in the youth of today: A teacher's perspective. Education and Training 58: 766-82. [CrossRef]

Blindenbach-Driessen, Floortje, Jan Van Dalen, and Jan Van Den Ende. 2010. Subjective performance assessment of innovation projects. Journal of Product Innovation Management 27: 572-92. [CrossRef]

Bloch, Carter, Mads P. Sørensen, Ebbe K. Graversen, Jesper W. Schneider, Evanthia Kalpazidou Schmidt, Kaare Aagaard, and Niels Mejlgaard. 2014. Developing a methodology to assess the impact of research grant funding: A mixed methods approach. Evaluation and Program Planning 43: 105-17. [CrossRef] [PubMed]

Blumberg, Boris, Donald Cooper, and Pamela Schindler. 2011. Business Research Methods. The International Journal of Accounting 42: 330-33.

Boerchers, Morrissa, Patricia Fitzpatrick, Christopher Storie, and Glen Hostetler. 2016. Reinvention through regreening: Examining environmental change in Sudbury, Ontario. Extractive Industries and Society 3: 793-801. [CrossRef]

Bouette, Martin, and Florence Magee. 2015. Hobbyists, artisans and entrepreneurs: Investigating business support and identifying entrepreneurial profiles in the Irish craft sector. Journal of Small Business and Enterprise Development 22: 337-51. [CrossRef]

Bryman, Alan. 2007. Barriers to Integrating Quantitative and Qualitative Research. Journal of Mixed Methods Research 1: 8-22. [CrossRef]

Burleson, Grace, Bryan Tilt, Kendra Sharp, and Nordica MacCarty. 2019. Reinventing boiling: A rapid ethnographic and engineering evaluation of a high-efficiency thermal water treatment technology in Uganda. Energy Research and Social Science 52: 68-77. [CrossRef]

Cameron, Roslyn. 2011. Mixed methods in business and management: A call to the 'first generation'. Journal of Management and Organization 17: 245. [CrossRef]

Cameron, Roslyn, and Jose F. Molina-Azorin. 2011. The acceptance of mixed methods in business and management research. International Journal of Organizational Analysis 19: 256-71. [CrossRef]

Camisón, César, and Ana Villar-López. 2014. Organizational innovation as an enabler of technological innovation capabilities and firm performance. Journal of Business Research 67: 2891-902. [CrossRef]

Cavanagh, Stephen. 1997. Content analysis: Concepts, methods and applications. Nurse Researcher 4: 5-16. [CrossRef]

Chasanidou, Dimitra, Njål Sivertstøl, and Jarle Hildrum. 2018. Exploring employee interactions and quality of contributions in intra-organisational innovation platforms. Creativity and Innovation Management 27: 458-75. [CrossRef]

Chen, Hsiang. 2006. Flow on the Net-Detecting Web Users' Positive Affects and Their Flow States. Computers in Human Behavior 22: 221-33. [CrossRef]

Chesbrough, Henry William, Wim Vanhaverbeke, and Joel West. 2006. Open Innovation: Researching a New Paradigm. Oxford: Oxford University Press.

Clark, Vicki Plano. 2005. Cross -Disciplinary Analysis of the Use of Mixed Methods in Physics Education Research, Counseling Psychology, and Primary Care. Lincoln: ETD Collection for University of Nebraska.

Cooper, R. Robert. 1990. Stage-gate systems: A new tool for managing new products. Business Horizons. [CrossRef]

Corsi, Christian, and Antonio Prencipe. 2018. Internal funding, debt and external equity: Which of these effectively improve the growth of university spin-offs? International Journal of Entrepreneurial Venturing 10: 638-62. [CrossRef]

Cortimiglia, Marcelo Nogueira, Antonio Ghezzi, and Alejandro Germán Frank. 2016. Business model innovation and strategy making nexus: Evidence from a cross-industry mixed-methods study. $R$ and $D$ Management 46: 414-32. [CrossRef]

Cowell, Margaret, Sarah Lyon-Hill, and Scott Tate. 2018. It takes all kinds: Understanding diverse entrepreneurial ecosystems. Journal of Enterprising Communities 12: 178-98. [CrossRef] 
Crammond, Robert, Kingsley Obi Omeihe, Alan Murray, and Kirstin Ledger. 2018. Managing knowledge through social media: Modelling an entrepreneurial approach for Scottish SMEs and beyond. Baltic Journal of Management 13: 303-28. [CrossRef]

Creswell, John, and David Creswell. 2018. Research Design: Qualitative, Quantitative, and Mixed Methods Approaches, 5th ed. New York: Sage Publications.

Creswell, John, and Vicki Plano Clark. 2017. Designing and Conducting Mixed Methods Research. New York: SAGE Publications, lnc.

Currall, Steven C., and Annette J. Towler. 2003. Research methods in management and organizational research: Toward integration of qualitative \& quantitative techniques. In Handbook of Mixed Methods in Social $\mathcal{E}$ Behavioral Research. Edited by A. Tashakkori and C. Teddlie. Thousand Oaks: Sage, pp. 513-26.

Dadfar, Hossein, Jens J. Dahlgaard, Staffan Brege, and Amir Alamirhoor. 2013. Linkage between organisational innovation capability, product platform development and performance: The case of pharmaceutical small and medium enterprises in Iran. Total Quality Management and Business Excellence 24: 819-34. [CrossRef]

de Miranda Santo, Marcio, Gilda Massari Coelho, Dalci Maria dos Santos, and Lélio Fellows Filho. 2006. Text mining as a valuable tool in foresight exercises: A study on nanotechnology. Technological Forecasting and Social Change 73: 1013-27. [CrossRef]

Denscombe, Martyn. 2008. Communities of practice: A research paradigm for the mixed methods approach. Journal of Mixed Methods Research 2: 270-83. [CrossRef]

Dosi, Giovanni. 1982. Technological paradigms and technological trajectories. A suggested interpretation of the determinants and directions of technical change. Research Policy 11: 147-62. [CrossRef]

Duarte, Paulo, and José Carlos Pinho. 2019. A mixed methods UTAUT2-based approach to assess mobile health adoption. Journal of Business Research 102: 140-50. [CrossRef]

Edling, Laura, and Cecilia Danks. 2018. To adopt or not to adopt? Insights on energy transitions from a study of advanced wood heating. Energy Research and Social Science 45: 331-39. [CrossRef]

Faems, Dries. 2020. Moving forward quantitative research on innovation management: A call for an inductive turn on using and presenting quantitative research. RED Management 50: 352-63.

Fellnhofer, Katharina. 2017a. Financing entrepreneurship by risk capital_Evidence revisited. Journal for International Business and Entrepreneurship Development 10: 173. [CrossRef]

Fellnhofer, Katharina. 2017b. Evidence revisited: Literature on smart specialisation calls for more mixed research designs. International Journal of Knowledge-Based Development 8: 229. [CrossRef]

Flores Ituarte, Iñigo, Sergei Chekurov, Jukka Tuomi, Julien Etienne Mascolo, Alessandro Zanella, Patrick Springer, and Jouni Partanen. 2018. Digital manufacturing applicability of a laser sintered component for automotive industry: A case study. Rapid Prototyping Journal 24: 1203-11. [CrossRef]

Frias, Kellilynn M., and Deidre Popovich. 2020. An experiential approach to teaching mixed methods research. Journal of Education for Business 95: 193-205. [CrossRef]

Fu, Lihua, Zhiying Liu, and Suqin Liao. 2018. Is distributed leadership a driving factor of innovation ambidexterity? An empirical study with mediating and moderating effects. Leadership and Organization Development Journal 39: 388-405. [CrossRef]

Geyskens, Inge, Rekha Krishnan, Jan-Benedict E M Steenkamp, and Paulo V. Cunha. 2009. A Review and Evaluation of Meta-Analysis Practices in Management Research. Journal of Management 35: 393-419. [CrossRef]

Ghaben, Rawan K., and Ayham A. M. Jaaron. 2017. Identifying and assessing innovation factors in construction projects in Palestine: An empirical study. International Journal of Project Organisation and Management 9: 350-73. [CrossRef]

Ghezzi, Antonio. 2019. Digital startups and the adoption and implementation of Lean Startup Approaches: Effectuation, Bricolage and Opportunity Creation in practice. Technological Forecasting and Social Change 146: 945-60. [CrossRef]

Goffin, Keith, Pär Åhlström, Mattia Bianchi, and Anders Richtnér. 2019. Perspective: State-of-the-art: The quality of case study research in innovation management. Journal of Product Innovation Management 36: 586-615. [CrossRef]

Greene, Jennifer C., Valerie J. Caracelli, and Wendy F. Graham. 1989. Toward a Conceptual Framework for Mixed-Method Evaluation Designs. Educational Evaluation and Policy Analysis 11: 255. [CrossRef] 
Grimpe, Christoph, Wolfgang Sofka, Mukesh Bhargava, and Rabikar Chatterjee. 2017. R\&D, Marketing Innovation, and New Product Performance: A Mixed Methods Study. Journal of Product Innovation Management 34: 360-83. [CrossRef]

Grimsby, Sveinung, and Cathrine Finne Kure. 2019. How open is food innovation? The crispbread case. British Food Journal 121: 950-63. [CrossRef]

Guidice, Rebecca M., Neal P. Mero, Lucy M. Matthews, and Juanne V. Greene. 2016. The influence of individual regulatory focus and accountability form in a high-performance work system. Journal of Business Research 69: 3332-40. [CrossRef]

Gupta, Praveen, and Brett E. Trusko. 2014. Global Innovation Science Handbook. New York: McGraw-Hill Education.

Hankammer, Stephan, Sebastian Brenk, Hannah Fabry, Anne Nordemann, and Frank T. Piller. 2019. Towards circular business models: Identifying consumer needs based on the jobs-to-be-done theory. Journal of Cleaner Production 231: 341-58. [CrossRef]

Harrison, Richard, William Scheela, P. C. Lai, and Sivapalan Vivekarajah. 2018. Beyond institutional voids and the middle-income trap: The emerging business angel market in Malaysia. Asia Pacific Journal of Management 35: 965-91. [CrossRef]

Hayter, Christopher S. 2016. Constraining entrepreneurial development: A knowledge-based view of social networks among academic entrepreneurs. Research Policy 45: 475-90. [CrossRef]

Hearst, Marti A., and Daniela Rosner. 2008. Tag clouds: Data analysis tool or social signaller? Paper presented at Annual Hawaii International Conference on System Sciences, Maui, HI, USA, January 3-6. [CrossRef]

Ho, Yuen Ping, Yi Ruan, Chang Chieh Hang, and Poh Kam Wong. 2016. Technology upgrading of Small-and-Medium-sized Enterprises (SMEs) through a manpower secondment strategy-A mixed-methods study of Singapore's T-Up program. Technovation 57-58: 21-29. [CrossRef]

Hoffmann, Stefan. 2011. Anti-consumption as a means to save jobs. European Journal of Marketing 45: 1702-14. [CrossRef]

Hofmann, Rupert. 2015. Visionary competence for long-term development of brands, products, and services: The trend receiver concept and its first applications at Audi. Technological Forecasting and Social Change 101: 83-98. [CrossRef]

Holis, Ym, Ibnu Syabri, and Hastu Prabatmojo. 2018. An Examination of Regional Competitiveness: Early Findings from Banten, Indonesia. Paper presented at 1st Itb Centennial and 4th Planocosmo Internationa 1 Conference, Bandung, Indonesia, April 3-5; vol. 158. [CrossRef]

$\mathrm{Hu}$, Zhiwen, and Ian McGrath. 2011. Innovation in higher education in China: Are teachers ready to integrate ICT in English language teaching? Technology, Pedagogy and Education 20: 41-59. [CrossRef]

Hwang, Reakook, and Hiroshi Katayama. 2009. A multi-decision genetic approach for workload balancing of mixed-model U-shaped assembly line systems. International Journal of Production Research 47: 3797-822. [CrossRef]

Ilonen, Sanna, Jarna Heinonen, and Pekka Stenholm. 2018. Identifying and understanding entrepreneurial decision-making logics in entrepreneurship education. International Journal of Entrepreneurial Behaviour and Research 24: 59-80. [CrossRef]

Imran, Ahmed, and Shirley Gregor. 2019. Conceptualising an IT mindset and its relationship to IT knowledge and intention to explore IT in the workplace. Information Technology and People 32: 1536-63. [CrossRef]

Islam, Nazrul, and Kumiko Miyazaki. 2009. NanoSI: Exploring nanotechnology research conflation and nano-innovation dynamism in the case of Japan. Science and Public Policy 36: 170-82. [CrossRef]

Iturrioz, Cristina, Cristina Aragón, and Lorea Narvaiza. 2015. How to foster shared innovation within SMEs' networks: Social capital and the role of intermediaries. European Management Journal 33: 104-15. [CrossRef]

Jafarnejad, Ahmad, Ali Mohaghar, Manochehre Manteghi, and Mehrdad Yasaei. 2014. Explore critical success factors of new product development in Iranian's food industry. Research Journal of Applied Sciences, Engineering and Technology 8: 1052-60. [CrossRef]

Jensen, Karina R. 2011. Creating Global Innovation Opportunities through Cross-cultural Collaboration. The International Journal of Knowledge, Culture, and Change Management: Annual Review 10: 33-42. [CrossRef]

Jick, Todd D. 1979. Mixing Qualitative and Quantitative Methods: Triangulation in Action. Administrative Science Quarterly 24: 602. [CrossRef]

Johnson, R. Burke, and Anthony J. Onwuegbuzie. 2004. Mixed Methods Research: A Research Paradigm Whose Time Has Come. Educational Researcher 33: 14-26. [CrossRef] 
JosephNg, Poh Soon. 2018. EaaS Optimization: Available yet hidden information technology infrastructure inside medium size enterprise. Technological Forecasting and Social Change 132: 165-73. [CrossRef]

Kapasi, Isla, and Galina Grekova. 2018. What do students think of self-determined learning in entrepreneurship education? Education and Training 60: 841-56. [CrossRef]

Kılkış, Şiir. 2017. Sustainable R\&D and innovation system comparisons of India, Russia, Mexico and Turkey. Management of Environmental Quality: An International Journal 28: 315-31. [CrossRef]

Kitchenham, Barbara. 2004. Procedures for Performing Systematic Reviews. Keele: Keele University.

Klingebiel, Ronald, and John Joseph. 2016. Entry timing and innovation strategy in feature phones. Strategic Management Journal 37: 1002-20. [CrossRef]

Kopcha, Theodore J., Lloyd P. Rieber, and Brandy B. Walker. 2016. Understanding university faculty perceptions about innovation in teaching and technology. British Journal of Educational Technology 47: 945-57. [CrossRef]

Korneta, Piotr. 2019. Critical success factors for Polish agricultural distributors. British Food Journal 121: 1565-78. [CrossRef]

Kraus, Sascha, Andreas Kallmuenzer, Daniel Stieger, Mike Peters, and Andrea Calabrò. 2018. Entrepreneurial paths to family firm performance. Journal of Business Research 88: 382-87. [CrossRef]

Kruger, Claudia, Rodrigo Goyannes Gusmão Caiado, Sergio Luiz Braga França, and Osvaldo Luiz Gonçalves Quelhas. 2018. A holistic model integrating value co-creation methodologies towards the sustainable development. Journal of Cleaner Production 191: 400-16. [CrossRef]

Lagos, Dimitrios, and Konstadinos Kutsikos. 2011. The role of IT-focused business incubators in managing regional development and innovation. European Research Studies Journal 14: 33-50. [CrossRef]

Lecossier, Adrien, Marc Pallot, Pascal Crubleau, and Simon Richir. 2019a. Towards radical innovations in a mature company: An empirical study on the UX-FFE model. Artificial Intelligence for Engineering Design, Analysis and Manufacturing: AIEDAM 33: 172-87. [CrossRef]

Lecossier, Adrien, Marc Pallot, Pascal Crubleau, and Simon Richir. 2019b. Construction of an instrument to evaluate the user eXperience of a group of co-creators in the upstream innovation process. International Journal of Services Operations and Informatics 10: 17-42. [CrossRef]

Leech, Nancy L., and Anthony J. Onwuegbuzie. 2009. A typology of mixed methods research designs. Quality and Quantity 43: 265-75. [CrossRef]

Lopes, Ana Paula Vilas Boas Viveiros, Kumiko Oshio Kissimoto, Mario Sergio Salerno, Marly Monteiro de Carvalho, and Fernando José Barbin Laurindo. 2016. Innovation management: A systematic literature analysis of the innovation management evolution. Brazilian Journal of Operations \& Production Management 13: 16. [CrossRef]

Lotka, Alfred. 1926. The Frequency Distribution of Scientific Productivity. Washington, DC: Washington Academy of Sciences.

Lucas, Kristen, Sharon A. Kerrick, Jenna Haugen, and Cole J. Crider. 2016. Communicating entrepreneurial passion: Personal Passion vs. Perceived Passion in venture pitches. IEEE Transactions on Professional Communication 59: 363-78. [CrossRef]

Lütjen, Heiner, Carsten Schultz, Frank Tietze, and Florian Urmetzer. 2019. Managing ecosystems for service innovation: A dynamic capability view. Journal of Business Research 104: 506-19. [CrossRef]

Malan, Leoné, Mark Hamer, Rolandvon Känel, Markus P. Schlaich, Manja Reimann, Nancy Frasure Smith, Gavin W. Lambert, Walthard Vilser, Brian H. Harvey, and Faans Steyn. 2019. Chronic depression symptoms and salivary NOx are associated with retinal vascular dysregulation: The SABPA study. Nitric Oxide 55-56: 10-17. [CrossRef]

Mason, Jennifer. 2006. Mixing Methods in a Qualitatively Driven Way, Qualitative Research. Thousand Oaks: Sage Publications, vol. 6, pp. 9-25. [CrossRef]

Maurice Khosa, Risimati, and Vivence Kalitanyi. 2015. Migration reasons, traits and entrepreneurial motivation of african immigrant entrepreneurs: Towards an entrepreneurial migration progression. Journal of Enterprising Communities 9: 132-55. [CrossRef]

McAdam, Maura, and Koenraad Debackere. 2018. Beyond triple helix toward quadruple helix models in regional innovation systems: Implications for theory and practice. RED Management 48: 3-6.

McCarthy, Breda, Hong Bo Liu, and Tingzhen Chen. 2016. Innovations in the agro-food system: Adoption of certified organic food and green food by Chinese consumers. British Food Journal 118: 1334-49. [CrossRef] 
Molina-Azorin, José F., Donald D. Bergh, Kevin Corley, and David J. Ketchen Jr. 2017. Mixed methods in the organizational sciences: Taking stock and moving forward. Organizational Research Methods 20: 179-92. [CrossRef]

Monsson, Christian Kjær, and Søren Berg Jørgensen. 2016. How do entrepreneurs' characteristics influence the benefits from the various elements of a business incubator? Journal of Small Business and Enterprise Development 23: 224-39. [CrossRef]

Morse, Janice M. 1991. Approaches to qualitative-quantitative methodological triangulation. Nursing Research 40: 120-23. [CrossRef]

Nambisan, Satish, and Priya Nambisan. 2008. How to profit from a better Virtual Customer Environment. MIT Sloan Management Review 49: 53-61.

Newbert, Scott L. 2007. Empirical research on the resource-based view of the firm: An assessment and suggestions for future research. Strategic Management Journal 28: 121-46. [CrossRef]

Niglas, Katrin. 2004. The Combined Use of Qualitative and Quantitative Methods in Educational Research. Ph.D. thesis, Tallinn Pedagogical University, Tallinn, Estonia. Available online: https://www.researchgate.net/publication/242406001_The_Combined_Use_of_Qualitative_and_Q uantitative_Methods_in_Educational_Research/citations (accessed on 20 October 2020).

O'Dwyer, Clare, and Kathryn Cormican. 2017. Regulation-Do or die: An analysis of factors critical to new product development in a regulatory context. Journal of Technology Management and Innovation 12: 26-38. [CrossRef]

Okoń-Horodyńska, Ewa, Anna Zachorowska-Mazurkiewicz, Rafal Wisła, and Tomasz Sierotowicz. 2020. New approach to create more effective teams in the innovation process in enterprises. Journal of Business Economics and Management 21: 805-25. [CrossRef]

Olsson, Annika, Karla Marie Karla, Ulf Johansson, Malin Olander Roese, and Sofia Ritzén. 2019. Organizational climate for innovation and creativity-A study in Swedish retail organizations. International Review of Retail, Distribution and Consumer Research 29: 243-61. [CrossRef]

Owusu-Manu, D., R. Quaigrain, and D. J. Edwards. 2015. Barriers constraining management innovation (MI) adoption in the Ghanaian construction consulting sector: A case study. Journal of Engineering, Design and Technology 13: 612-31. [CrossRef]

Pereira, Dina, and João Leitão. 2016. Absorptive capacity, coopetition and generation of product innovation: Contrasting Italian and Portuguese manufacturing firms. International Journal of Technology Management 71: 10-37. [CrossRef]

Perenyi, Aron, Roxanne Zolin, and Alex Maritz. 2018. The perceptions of Australian senior entrepreneurs on the drivers of their entrepreneurial activity. International Journal of Entrepreneurial Behaviour and Research 24: 81-103. [CrossRef]

Price, Derek John de Solla. 1986. Little Science, Big Science and Beyond. New York: Columbia University Press.

R Core Team. 2018. R: A Language and Environment for Statistical Computing. Vienna: R Foundation for Statistical Computing.

Radovanović, Nikola, Veljko Dmitrović, and Nevenka Žarkić Joksimović. 2017. From knowledge to innovation and back: Empirical testing of knowledge-intensive industries in Serbia. Entrepreneurial Business and Economics Review 5: 119-31. [CrossRef]

Reinhardt, Ronny, and Sebastian Gurtner. 2018. The overlooked role of embeddedness in disruptive innovation theory. Technological Forecasting and Social Change 132: 268-83. [CrossRef]

Ritala, Paavo, Sabrina Schneider, and Snejina Michailova. 2020. Innovation management research methods: Embracing rigor and diversity. RED Management 50: 297-308.

Ritchie, Jane, Jane Lewis, Carol McNaughton Nicholls, and Rachel Ormston, eds. 2013. Qualitative Research Practice: A Guide for Social Science Students and Researchers. Thousand Oaks: Sage.

Rousseau, Denise M., Joshua Manning, and David Denyer. 2008. Evidence in management and organizational science: Assembling the field's full weight of scientific knowledge through syntheses. The Academy of Management Annals 2: 475-515. [CrossRef]

Sandelowski, Margarete, and Julie Barroso. 2003. Creating metasummaries of qualitative findings. Nursing Research 52: 226-33. [CrossRef]

Saunila, Minna. 2017. Understanding innovation performance measurement in SMEs. Measuring Business Excellence 21: 1-16. [CrossRef] 
Sawhney, Mohanbir, and Emanuela Prandelli. 2000. Communities of Creation: Managing Distributed Innovation in Turbulent Markets. California Management Review 42: 24-54. [CrossRef]

Shea, Christine M. 2005. Future management research directions in nanotechnology: A case study. Journal of Engineering and Technology Management-JET-M 22: 185-200. [CrossRef]

Shen, Yi. 2019. Create synergies and inspire collaborations around the development of intelligent infrastructure for human-centered communities. Journal of the Association for Information Science and Technology 70: 596-606. [CrossRef]

Singh, Vishal, and Jan Holmstrom. 2015. Needs and technology adoption: Observation from BIM experience. Engineering, Construction and Architectural Management 22: 128-50. [CrossRef]

Siripongdee, Surapong, and Wanno Fongsuwan. 2015. Thailand's provincial electricity authority queuing performance management system. Research Journal of Business Management 9: 47-67. [CrossRef]

Spiegel, Markus, and Christian Marxt. 2015. Understanding and breaking innovation lock-in effects. International Journal of Entrepreneurial Venturing 7: 266-85. [CrossRef]

Straka, Milan, and Jana Straková. 2017. Tokenizing, POS Tagging, Lemmatizing and Parsing UD 2.0 with UDPipe 88-99. Available online: https://www.aclweb.org/anthology/K17-3009.pdf (accessed on 19 October 2020).

Swartz, Ethné, Frances M. Amatucci, and Susan Coleman. 2016. Using a multiple method and mixed mode approach to examine women entrepreneur negotiating styles. International Journal of Gender and Entrepreneurship 8: 48-68. [CrossRef]

Szczepańska-Woszczyna, Katarzyna. 2020. Management Theory, Innovation, and Organisation. A Model of Managerial Competencies. London: Routledge.

Szczepańska-Woszczyna, Katarzyna, and Zdzisława Dacko-Pikiewicz. 2014. Managerial Competencies and Innovations in the Company-The Case of Enterprises in Poland. Business, Management and Education 12: 266-82. [CrossRef]

Tashakkori, Abbas, and John Creswell. 2007. The new era of mixed methods. Journal of Mixed Methods Research 1: 3-7. [CrossRef]

Tashakkori, Abbas, and Charles Teddlie. 1998. Mixed Methodology: Combining Qualitative and Quantitative Approaches. Thousand Oaks: Sage Publications.

Teirlinck, Peter, and André Spithoven. 2013. Formal R\&D management and strategic decision making in small firms in knowledge-intensive business services. $R$ and D Management 43: 37-51. [CrossRef]

Teixeira, Eduardo Kunzel, Mirian Oliveira, and Carla Curado. 2019. Linking knowledge management processes to innovation: A mixed-method and cross-national approach. Management Research Review. [CrossRef]

Thomas, Ashish. 2017. Multivariate hybrid pathways for creating exceptional customer experiences. Business Process Management Journal 23: 822-29. [CrossRef]

Thurston, Wilfreda E., Leslie Cove, and Lynn M. Meadows. 2008. Methodological congruence in complex and collaborative mixed method studies. International Journal of Multiple Research Approaches 2: 2-14. [CrossRef]

Tidd, Joe, and John Bessant. 2018a. Managing Innovation: Integrating Technological, Market and Organizational Change. Hoboken: John Wiley \& Sons.

Tidd, Joe, and John Bessant. 2018b. Innovation management challenges: From fads to fundamentals. International Journal of Innovation Management 22: 1840007. [CrossRef]

Timma, Lelde, Andra Blumberga, and Dagnija Blumberga. 2015. Combined and Mixed Methods Research in Environmental Engineering: When Two is Better Than One. In Energy Procedia. Amsterdam: Elsevier Ltd., pp. 300-6. [CrossRef]

Titarenko, Boris, Sergey Titov, and Roman Titarenko. 2014. Risk Management in Innovation Projects. Applied Mechanics and Materials 640: 2338-41. [CrossRef]

Tranfield, David, David Denyer, and Palminder Smart. 2003. Towards a Methodology for Developing Evidence-Informed Management Knowledge by Means of Systematic Review. British Journal of Management 14: 207-22. [CrossRef]

Tu, Mengru. 2018. An exploratory study of internet of things (IoT) adoption intention in logistics and supply chain management a mixed research approach. In International Journal of Logistics Management. Bingley: Emerald Group Publishing Ltd., pp. 131-51. [CrossRef]

Udawatta, Nilupa, Jian Zuo, Keri Chiveralls, and George Zillante. 2015. Improving waste management in construction projects: An Australian study. Resources, Conservation and Recycling 101: 73-83. [CrossRef] 
van de Burgwal, Linda H. M., Ana Dias, and Eric Claassen. 2019. Incentives for knowledge valorisation: A European benchmark. Journal of Technology Transfer 44. [CrossRef]

van Eck, Nees Jan, and Ludo Waltman. 2010. How to normalize cooccurrence data? An analysis of some well-known similarity measures. Journal of the American Society for Information Science and Technology 60: 1635-51.

Vicente-Oliva, Silvia, Ángel Martínez-Sánchez, and Luis Berges-Muro. 2016. Enhancing the outcomes in R\&D collaborative projects: An empirical analysis of the middle ebro valley in Spain. International Journal of Innovation Management 20. [CrossRef]

Wach, Krzysztof. 2016. Innovative Behaviour of High-Tech Internationalized Firms: Survey Results from Poland. Entrepreneurial Business and Economics Review 4: 153-65. [CrossRef]

Walravens, Nils. 2015. Mobile city applications for Brussels citizens: Smart City trends, challenges and a reality check. In Telematics and Informatics. Amsterdam: Elsevier Ltd., pp. 282-99. [CrossRef]

Walwyn, David, Andreas Bertoldi, and Christian Gable. 2019. Building the hydrogen economy through niche experimentation and digitalisation. Journal of Manufacturing Technology Management 30: 1179-95. [CrossRef]

Wheelwright, Steven C., and Kim B. Clark. 1992. Revolutionizing Product Development: Quantum Leaps in Speed, Efficiency, and Quality. New York: Free Press.

Wipulanusat, Warit, Kriengsak Panuwatwanich, Rodney Anthony Stewart, and Jirapon Sunkpho. 2020. Applying Mixed Methods Sequential Explanatory Design to Innovation Management. In The 10th International Conference on Engineering, Project, and Production Management. Singapore: Springer, pp. 485-95.

Yetis Larsson, Zeynep, Paul M. Di Gangi, and Robin Teigland. 2019. Sharing my way to success: A case study on developing entrepreneurial ventures using social capital in an OSS community. Information and Organization 29: 23-40. [CrossRef]

Yström, Anna, Hedvig Aspenberg, and Annika Kumlin. 2015. Exploring the creative climate in an open innovation arena: Identifying challenges and possibilities. European Journal of Innovation Management 18: 70-85. [CrossRef]

Publisher's Note: MDPI stays neutral with regard to jurisdictional claims in published maps and institutional affiliations.

(C) 2020 by the authors. Licensee MDPI, Basel, Switzerland. This article is an open access article distributed under the terms and conditions of the Creative Commons Attribution (CC BY) license (http://creativecommons.org/licenses/by/4.0/). 